\title{
1 Life Cycle Assessment and Life Cycle Costing of road 2 infrastructure in residential neighbourhoods
}

3 Trigaux D., Wijnants L., De Troyer F., Allacker K.

4 Department of Architecture, Faculty of Engineering Science, KU Leuven, Kasteelpark Arenberg 1, 3001

5 Leuven, Belgium

6 damien.trigaux@asro.kuleuven.be, +3216321376

7 This article was published in the International Journal of Life Cycle Assessment (Springer 2016). The final 8 publication is available at http://link.springer.com/article/10.1007\%2Fs11367-016-1190-X

9

\section{Abstract}

Purpose The built environment consists of a huge amount of infrastructure, such as roads and utilities. The objective of this paper is to assess the life cycle financial and environmental impact of road infrastructure in residential neighbourhoods and to analyse the relative contribution of road infrastructure in the total impact of neighbourhoods.

Methods Various road sections are analysed based on an integrated life cycle approach, combining Life Cycle Costing and Life Cycle Assessment. To deal with complexity, a hierarchic assessment structure, using the principles of the "element method for cost control”, is implemented. Four neighbourhood models with diverse built densities are compared to gain insight in the relative impact of road infrastructure in neighbourhoods.

Results The results reveal important financial and environmental impact differences between the road sections analysed. Main contributors to the life cycle financial and environmental impact are the surface layer and electrical and piped services. The contribution of road infrastructure to the total neighbourhood impact, ranging from $2 \%$ to $9 \%$ of the total cost, is relatively limited, compared to buildings, but not negligible in low built density neighbourhoods.

Conclusions and recommendations Good spatial planning of the neighbourhood is recommended to reduce the amount of road infrastructure and the related financial and environmental impact. The priority should be to design denser neighbourhood layouts, before decreasing the financial and environmental impact of the road sections.

Keywords: construction works; element method for cost control; environmental impact; economic assessment; neighbourhood layout; built density 


\section{Introduction}

Urban sprawl has become a challenge for most developed countries due to its major impact on mobility, energy and land use. Between 1980 and 2000, the built-up area in Europe increased by about 20\% (European Environment Agency 2006). This expansion is responsible for a huge amount of infrastructure such as roads and utilities. In the same period the road network in Europe expanded by about 10\% (European Environment Agency 2006). In order to move towards a sustainable built environment, not only the characteristics of individual buildings should be considered but also the relation between urban morphology, built density and the required infrastructure.

During the most recent decades the environmental impact of road infrastructure has been extensively studied. A review of existing Life Cycle Assessment (LCA) studies of road infrastructure can be found in (Carlson 2011) and (Santero et al. 2011). Some of these studies analyse the environmental impact of asphalt pavement (Waterford County Council et al. 2010; Butt 2012) or compare the environmental impact of different pavement types (Stripple 2001; Hoang et al. 2005; Gschösser 2011). Other studies focus on the impact of the surface layer on the traffic fuel consumption during the use phase (Araújo et al. 2014) or on maintenance strategies (Giustozzi et al. 2012; Jullien et al. 2014), while others focus on the influence of methodological choices (Huang et al. 2013) or parameter uncertainty (Noshadravan et al. 2013) on decision making.

The results obtained by these studies are often not comparable because different environmental impact categories and/or life cycle phases are considered (Carlson 2011). Moreover, due to context-dependent aspects and local construction techniques the road sections analysed differ in design traffic load, life span and/or composition.

Despite the differences observed between the existing studies, some general conclusions can be drawn from them. First, the production of road materials has a high influence on the life cycle environmental impact (Mroueh et al. 2001; Weiland 2008; Gschösser 2011), with bitumen in asphalt pavement and cement in concrete pavement as main contributors (Häkkinen and Mäkelä 1996; Hoang et al. 2005). Second, the road maintenance plays a significant role in the life cycle environmental impact (Gschösser 2011; Giustozzi et al. 2012; Jullien et al. 2014). According to (Jullien et al. 2014), about 1/3 of the life cycle environmental impact is caused by maintenance operations. Third, several studies revealed that traffic fuel consumption during the use phase causes a considerable environmental impact which is much higher than the impact of the road construction and maintenance (Stripple 2001; Mroueh et al. 2001; Araújo et al. 2014). For example, (Stripple 2001) analysed the share of the energy use due to a traffic intensity of 5000 vehicles per day and concluded that the energy consumption for the construction, maintenance and operation of the road (including the energy consumption for road lighting and traffic control) is between $9.9 \%$ and $11.8 \%$ of the energy use due to traffic. As the rolling resistance affect the vehicle fuel 
consumption, several studies hence recommend to include the influence of the road surface characteristics on the traffic fuel consumption in the analysis (Santero et al. 2010; Carlson 2011). Finally, preferences between various pavement types are influenced by the environmental impact indicators considered (Häkkinen and Mäkelä 1996; Weiland 2008; Gschösser 2011). A comparison of asphalt and concrete pavement by (Weiland 2008), for instance, revealed that concrete pavement contributes more to global warming potential and human health impacts, while asphalt pavement causes a higher impact on acidification, eutrophication and photochemical smog.

In addition to the assessment of the environmental impact, Life Cycle Costing (LCC) is increasingly used in the transport sector. In the United States, the Federal Highway Administration provided a technical bulletin to conduct LCC (Walls and Smith 1998) and developed a specific software "RealCost" to support the evaluation of the financial impact of road infrastructure (FHWA 2011). A state-of-the-practice concerning the use of LCC in the United States, Europe and Canada can be found in (Rangaraju et al. 2008). Existing LCC studies of roads focus on the comparison of different pavement types (Gschösser 2011; Holt et al. 2011; Scheving 2011) or on the analysis of pavement preventive maintenance (Giustozzi et al. 2012; Ding et al. 2013). From these studies the following can be concluded. First, preferences between different pavement types depend on the traffic intensity. Compared to asphalt pavement, concrete pavement is more expensive but becomes more competitive for a higher traffic intensity. The reasons are lower maintenance frequencies for concrete and a limited increase in concrete thickness for a higher traffic intensity (Holt et al. 2011; Scheving 2011). Second, the maintenance strategy has a major influence on the life cycle financial cost. (Gschösser 2011) reported reduction potentials of $15 \%$ for asphalt pavement to $23 \%$ for concrete pavements by optimizing maintenance strategies.

Only a limited number of studies consider the financial and environmental impact jointly, such as (Gschösser 2011) and (Giustozzi et al. 2012), and no detailed impact assessment of road infrastructure in residential neighbourhoods is known by the authors.

This paper aims at contributing to the field by assessing the life cycle financial cost and environmental impact of road infrastructure in residential neighbourhoods and to contextualise this in the total cost and impact of these neighbourhoods. This paper is based on previous research (Trigaux et al. 2014; Wijnants 2014) on the environmental impact of road infrastructure, which is integrated and further extended by adding an assessment of the life cycle financial cost.

The methodology is described in section two and illustrated in section three by assessing various sections for local roads and bicycle paths. To analyse the contribution of the road infrastructure in the total impact of the 
neighbourhood, four neighbourhood models with diverse built densities are assessed. Conclusions and recommendations are formulated in section four.

\section{Methods}

\subsection{Integrated life cycle approach}

The assessment of the life cycle financial and environmental impact of road infrastructure is based on the sustainability evaluation method for buildings developed in a previous research project, SuFiQuaD (“Sustainability, Financial and Quality Evaluation of Dwelling Types”) (Allacker 2010; Allacker et al. 2013b). This method follows an integrated life cycle approach combining LCC and LCA. The entire life cycle of the building is considered, including the initial stage, use stage and end-of-life (EOL) stage. The SuFiQuaD method was developed to assess and optimise the financial and environmental impact of a number of dwelling types representative for the Belgian context. In this paper the SuFiQuaD method is extended to the neighbourhood level by including the financial and environmental impact of road infrastructure in residential neighbourhoods.

\subsection{Life Cycle Costing (LCC)}

The financial costs during the various life cycle stages are considered within the LCC approach. These include the investment cost (i.e. material, labour and indirect costs for initial construction), cleaning, maintenance, replacement and energy costs during the use phase and costs for demolition and waste treatment during the EOL stage. In the SuFiQuaD project, the financial data for the building components are mainly based on the Belgian cost database ASPEN (ASPEN 2008a; ASPEN 2008b), combined with product specific data. As a Belgian cost database for neighbourhood infrastructure is lacking, the British Spon's Price Books "External works and landscape price book" (Spon press 2015a) and "Civil engineering and highway works price book" (Spon press 2015b), are used for price data related to external works and road infrastructure. The life cycle financial cost is calculated as the sum of the present values (for the reference year 2015) of all costs occurring during the life cycle of the road infrastructure. The economic parameters - in real terms - are based on Belgian statistical data and are summarized in Table 1.

\section{Table 1 here}

\subsection{Life Cycle Assessment (LCA)}

The environmental impact assessment method used in SuFiQuaD was recently updated within the MMG (“Environmental profile of building elements”) project, commissioned by the Public Waste Agency of Flanders (Allacker et al. 2013a), in order to be in line with recent developments in Europe (CEN 2011; EC-JRC 2011; CEN 2013). 
Concerning the included life cycle processes, the initial stage covers the production of building materials (including raw material extraction and transport to the production site), transport to the construction site and construction activities. The use stage includes processes related to cleaning, maintenance, replacement of components and energy use. Finally, the EOL stage covers the demolition activities, waste transport and waste treatment.

Regarding the selected environmental indicators, the impact categories in the MMG method (see Table 2) include the ones defined by the CEN TC350 standards (CEN 2011; CEN 2013), which are further referred to as CEN indicators. In addition, seven more impact categories are considered based on the International Reference Life Cycle Data System (ILCD) Handbook (EC-JRC 2011) and consultation of Belgian policy makers and administrations. The additional impact categories are further referred to as CEN+ indicators.

The MMG method includes - besides the characterised scores per impact category - an aggregated single-score indicator, expressed in a monetary value (EURO), indicating the external environmental cost. This external environmental cost is calculated by multiplying the characterised environmental impact indicators with their specific monetary value and adding these up to obtain the overall environmental cost (single score). An overview of the monetary values for each impact category, including a median, minimum and maximum scenario is given in Electronic supplementary material, Table. S.1 and S.2. In this paper, the median monetary values are used but sensitivity analyses are done, based on the minimum and maximum scenarios. Compared to other weighting methods, the advantage of expressing environmental impacts in monetary values is the possibility to internalize environmental externalities by calculating the sum of the financial and environmental costs, further referred to as total cost. Similar to the financial cost calculation, discounting of future environmental cost is applied, based on a real social discount rate of $1 \%$ (see Table 1). In literature, the use of a social discount rate, lower than the private discount rate, is generally assumed for cost in connection with collective decisions (Allacker 2010).

Table 2 here The Ecoinvent database (version 2.2) is used for the life cycle inventory (LCI) (Frischknecht et al. 2007). Preference is given to Western European processes to ensure the representativeness for the Belgian context. When generic Western European processes are lacking, Swiss data records are adapted by replacing the Swiss electricity mix and transport processes by European corresponding processes, assuming that construction products on the Belgian market are imported from several EU Member States (Allacker et al. 2013a). For specific materials, such as road asphalt, concrete and paint, new records were defined by modifying the quantities and/or underlying processes in existing similar records. 


\subsection{Element method for cost control}

150

151

152

153

154

155

156

157

158

159

160

161

162

163

164

165

166

167

168

169

170

171

172

173

174

175

176

177

178

The structure of the SuFiQuaD method is based on the element method for cost control (Allacker 2010). The financial and environmental impact calculations are structured according to a hierarchical subdivision of the building into functional elements, such as external walls, external finishing of external walls and support for external finishing of external walls. For all those elements, defined by their function, different technical solutions are possible, each using one or more building materials. In consequence, an analysis can be made at various scale levels: building materials (e.g. brick, mortar, plaster), work sections (e.g. brickwork, plasterwork), building elements (e.g. external wall including finishes) and buildings. In previous research (Trigaux et al. 2014), this approach was extended to evaluate neighbourhoods, which are defined as a combination of buildings, networks (e.g. roads, utilities) and open spaces (Fig. 1).

\section{Fig. 1 here}

The implementation of the element method is based on the BB/SfB-plus classification (De Troyer 2008), which is an extension of the Belgian version (De Troyer et al. 1990) of the international CI/SfB classification system (RayJones and Clegg 1978). Constructions outside the building, such as road infrastructure or utilities, are classified in “(9-) External works” (Fig. 2). In this research the functional elements “(94) Ground surface treatments”, “(95) Piped services” and “(96) Electrical services” are used to evaluate the impact of road infrastructure and the adjacent piped and electrical services.

Fig. 2 here

\subsection{Case studies}

\subsubsection{Description of the road infrastructure}

Various sections of a two-lane road for local traffic are considered in the analysis. The variants are representative for Belgium and their composition is summarised in Fig. 3 and Table 3. The roads considered are five metres wide and are composed of a geotextile, a sub-base, a base and a surface layer. Piped services, including drink water, gas and sewer pipes, and electrical services, including road lighting, electric and data cables, are considered as well. Five variants for the surface layer are compared, i.e. asphalt, concrete, reused cobblestone, concrete paving stones and water-permeable concrete stones (Road 1 to 5). Three alternatives for the type of base and sub-base and the sewer system are analysed (Road 6 to 8). For the base and sub-base, the use of crushed gravel instead of rubble is considered. For the sewer system, the concrete storm sewer pipe and vitrified clay sanitary sewer pipe are replaced by polyvinylchloride (PVC) pipes or lightweight ribbed polypropylene (PP) pipes. A detailed overview of the road sections can be found in the Electronic supplementary material, Table S.3. 
Fig. 3 here

Besides local roads, bicycle paths and footpaths have been assessed. As the sections of the bicycle paths and footpaths are quite similar, only the bicycle paths are further discussed in this paper. The bicycle paths are 1.75 metres wide and are composed of a geotextile, a base and a surface layer (Electronic supplementary material, Fig. S.1 and Table S.4). Five variants for the surface layer are compared, i.e. asphalt, concrete, concrete paving stones, water-permeable concrete stones and concrete tiles (Bicycle path 1 to 5). As red coloured bicycle paths are often used by municipalities for security reasons, four alternative colouring systems are analysed: red road paint, red cold plastic coating, red pigmented concrete and red pigmented concrete paving stones (Bicycle path 6 to 9). 2.5.2 Description of the neighbourhood models

To gain insight in the relative impact of road infrastructure in neighbourhoods, four neighbourhood models composed of representative Belgian dwelling types are defined. These consist of respectively detached houses (Model 1), semi-detached houses (Model 2), terraced houses (Model 3) and apartments (Model 4) (Fig. 4). The models differ in built density with a Floor Space Index, ranging from 0.21 in Model 1 to 1.13 in Model 4. Each building type leads to a different amount of road infrastructure per floor area, ranging from $0.02 \mathrm{~m} \mathrm{road} / \mathrm{m}^{2}$ floor in Model 4 to $0.1 \mathrm{~m} \mathrm{road} / \mathrm{m}^{2}$ floor in Model 1.

Fig. 4 here

A detailed description of the dwelling types can be found in Electronic supplementary material (Fig S.2, Fig. S.3, Fig. S.4 and Fig. S.5). The dwellings are composed of standard building elements from the database of the MMG project, including brick loadbearing walls, concrete floors and a timber pitched roof or concrete flat roof (Electronic supplementary material, Table. S.5). Only the space delimiting elements (i.e. floors, walls, roofs, stairs, windows and doors) are considered. The technical systems (e.g. heating, ventilation and water supply) are not included in the analysis. For each dwelling the impact of the energy use for heating due to transmission losses is estimated based on the equivalent degree day method (Allacker 2010). Infiltration and ventilation losses are not included since they are not depending on the materials used, but rather on the construction quality and the ventilation system and settings.

Concerning the road infrastructure, one variant of the analysed roads, bicycle paths and footpaths, was selected for the analysis at the neighbourhood level. In the different models, the road infrastructure consists of an asphalt road (including piped and electrical services) with a bicycle path and footpath in concrete paving stones on both sides. 
This paper includes two types of analyses. First, an analysis is carried out at the level of the road infrastructure. The life cycle impact of various sections for local roads and bicycle paths is assessed, including the impact of the adjacent services and energy use for road lighting. Furthermore, for the road sections with a concrete and cobblestone surface layer, an additional assessment, including the impact of car traffic during the use stage, is done to identify the influence of the road surface layer on the fuel energy consumption. Second, an analysis is carried out at the neighbourhood level, looking at the life cycle impact of buildings (including the impact of energy use for heating), together with the required road infrastructure (including the impact of adjacent services and energy use for road lighting). In this analysis the impact of car traffic was not taken into account as it would require a more detailed study of the transport movements in the analysed neighbourhood models, which was out of the scope of this research.

Concerning the analysis at the level of the road infrastructure, the impact is expressed per metre road of the entire road section (including one or more lanes). This allows to compare a wide range of infrastructure components, such as roads, bicycle paths and footpaths. To compare the alternatives in a meaningful way, a number of design parameters are defined, such as the required road width and design load. Although the road composition influences various quality aspects such as the driving comfort, noise generation, rolling resistance and safety, this research does not include an in-depth evaluation of those performances.

The assumptions regarding the life span for road infrastructure vary among the studies reviewed. (Stripple 2001) uses a life span of 40 or 60 year. (Gschösser 2011) makes an analysis based on 25, 50 and 75 year. In this research, a life span of 60 year is assumed for Belgian local roads, corresponding to the average technical life span of sewer pipes (Egyed et al. 2008; Oosterom and Hermans 2013), as the replacement of sewer pipes often results in a complete reconstruction of the road. For the road components that have not reached their technical life span after 60 year, no residual value is considered in the calculations as the whole infrastructure is assumed to be demolished. Concerning the analysis at the neighbourhood level, the impact is analysed per square metre of floor area of the buildings, allowing to compare different neighbourhood layouts and typologies. A life span of 60 years is assumed, which corresponds to the average life span of dwellings in Belgium (Allacker 2010).

\subsection{Life cycle scenarios}

Scenarios have been defined concerning the transport of building materials, cleaning, maintenance and replacement processes, energy use and EOL. The scenarios related to building elements are described in the publications of the SuFiQuaD and MMG projects (Allacker 2010; Allacker et al. 2013a; Allacker et al. 2013b). In this paper, the scenarios and assumptions, which are specific for the road infrastructure, are summarised. 
Concerning the environmental impact assessment, the impact of road construction equipment, such as asphalt and concrete paving machines, is calculated based on inventory data reported in (Gschösser 2011). Regarding the use stage, the cleaning of roads and sewers is not considered, in contrary to the cleaning of buildings, because financial and environmental data are lacking. Scenarios for maintenance and replacements of road components are based on publications from the road construction sector and existing LCA studies (Wijnants 2014). As the focus of this paper is on local roads, relatively low replacement frequencies are assumed for the surface layers, i.e. 30 year for asphalt and 40 year for concrete, concrete tiles and concrete paving stones. For the cobblestone pavement, no replacement is considered during the road life span but a relay of the stones every 20 year is assumed. It should however be noticed that for asphalt top layers, higher replacement frequencies of 12 to 20 year are found in the literature for roads with a more intensive traffic load (Gschösser 2011). The results of the comparison between different road surface layers are therefore only applicable for low traffic roads and should not be interpreted in general terms. An overview of the maintenance and replacement scenarios is given in Table 4 . The same scenarios are used for the roads and bicycle paths, as the analysed bicycle paths are not physically separated from car traffic. Concerning road lighting, the energy consumption is calculated assuming energy efficient lighting lanterns of $70 \mathrm{~W}$, placed every $20 \mathrm{~m}$ on one side of the road, and with an average lighting period of 12 hours per day.

Table 4 here

\section{Results}

\subsection{Assessment of the road infrastructure}

The LCA and LCC results for the local roads and bicycle paths are discussed in the subsequent paragraphs. In order to show the relative importance of car traffic during the use stage in the global environmental impact, this aspect is analysed in a separated paragraph. As mentioned above, the results are only applicable to local roads with a low traffic load, as the replacement frequencies for surface layers are highly dependent on the traffic intensity. The results should therefore not be interpreted in general terms.

\subsubsection{LCA and LCC of roads}

263 The life cycle environmental cost of the analysed road sections is shown in Fig. 5. The results are subdivided per life cycle phase (i.e. from the production to the EOL) and expressed in euro per metre road (present value over a life span of 60 year). The analysis of the first road section (i.e. a bituminous asphalt road) reveals that the production phase contributes most to the environmental profile and represents $47 \%$ of the life cycle environmental cost of the road. Besides the production, the energy use for road lighting causes a significant environmental impact with a contribution of $15 \%$ to the life cycle impact. This is much higher than the impact of the lighting lanterns and columns, which represent only $2 \%$ of the life cycle impact (Fig. 6). The transport to the construction site and 
replacement of the work sections contribute to about $10 \%$ of the environmental cost. Concerning the replacement of work sections, the environmental impact is mainly due to the replacement of the surface layer every 30 years. The latter emphasizes the importance of the replacement strategies for the surface layers. Finally, the construction, maintenance, waste transport and waste treatment have a negligible impact, with a contribution of less than $5 \%$ to the life cycle environmental cost.

\section{Fig. 5 here}

The analysis of the different work sections (Fig. 6) reveals that the asphalt layers of the first road section (Road 1) contribute $21 \%$ to the life cycle environmental cost. Furthermore the environmental cost of the electric and data cables is remarkably high (i.e. $28 \%$ of the life cycle environmental cost) due to the high environmental cost of copper, used in electric cables. This high environmental cost results mainly from the impact categories freshwater eutrophication, human toxicity, particulate matter formation and abiotic depletion of non-fossil fuels. Compared with the surface layers, the base and sub-base have a low environmental impact as there is no maintenance or replacement of these during the life span of the road.

When comparing asphalt with four alternative surface layers, (Fig. 5 and Fig. 6), the cobblestone surface layer causes the lowest environmental cost, i.e. a reduction of $71 \%$ compared to the asphalt surface layer, mainly due to the use of reclaimed cobblestones. Compared to asphalt, the concrete surface layer has a 5\% higher environmental impact due to a higher environmental cost for production. Despite a higher environmental cost for production, surface layers in concrete paving stones and permeable concrete paving stones cause respectively a $10 \%$ and $14 \%$ lower environmental impact, compared to asphalt, which can be explained by the lower environmental cost for the replacement of these. However, for the permeable concrete stones, the lower impact of the surface layer is largely compensated by an increase in the impact of the road base, consisting of porous lean concrete instead of cement bonded crushed rubble.

Finally, alternatives for the type of base and sub-base and the sewerage system are analysed (Road 6-Road 8). Using gravel instead of rubble for the base and sub-base leads to a small increase of $3 \%$ in the environmental cost of those work sections. This is because the environmental cost of gravel mainly results from the crushing process which is also required for the production of rubble. Replacing the concrete storm sewer pipe and vitrified clay sanitary sewer pipe by polyvinylchloride (PVC) pipes does not influence the environmental impact. Replacing these by lightweight ribbed polypropylene (PP) pipes results in a reduction of $10 \%$ of the environmental cost of the sewer pipes, due to a lower impact for production (Fig. 5). 
As the analysed road sections only differ in the composition of a few work sections, differences in total environmental cost, compared to the asphalt road, are limited to maximum $2 \%$, except for the cobblestone road (Road 3) which impact is $14 \%$ lower.

The life cycle environmental cost per impact category for the asphalt road and the eight variants is shown respectively in Fig. 7 and in the Electronic supplementary material, Fig. S.6. Nine of the sixteen impact categories considered have a negligible impact: ozone depletion, terrestrial acidification, ionising radiation: human health, terrestrial ecotoxicity, freshwater ecotoxicity, land occupation: forest, urban land occupation, transformation tropical rain forest. Remarkable is the relatively low impact on climate change, marine eutrophication, photochemical oxidant formation and particulate matter formation of the road section with reclaimed cobblestones compared to the other road sections. Regarding freshwater eutrophication, abiotic depletion of non-fossil fuels and human toxicity, the impact is similar for all the road sections analysed because these impact categories are dominated by the contribution of electric and data cables, which are identical in all variants. When comparing the concrete road with the asphalt road, the impact of climate change and particulate matter formation is respectively $16 \%$ and $6 \%$ higher for the concrete road, while the impact of marine eutrophication and photochemical oxidant formation is respectively $19 \%$ and $13 \%$ lower for the concrete road.

Fig. 7 here

As sensitivity analyses, the LCA results are calculated based on the monetary values defined in the minimum and maximum scenarios (Electronic supplementary material, Fig. S.7 and S.8). Compared to the median scenario, the life cycle environmental cost of the road sections is about $75 \%$ lower for the minimum scenario and about $410 \%$ higher for the maximum scenario. However the chosen scenario has no influence on the preferences between the road sections and the abovementioned conclusions. For reasons of transparency, the characterized (not weighted) results of the environmental impact assessment are reported in Electronic supplementary material Table S.6. Beside the analysis of the environmental impact, the life cycle financial cost of the road sections is calculated. The results are shown in Fig. 8 and Fig. 9. Similar conclusions as for the environmental cost can be drawn for the asphalt road (Road 1): the investment cost is the highest (60\% of the life cycle financial cost) followed by the replacement cost of sub-elements ( $21 \%$ of the life cycle financial cost). The maintenance and waste treatment have a negligible impact, with a contribution of less than $5 \%$ to the life cycle financial cost. In contrast to the environmental cost, the financial cost of energy use for lighting is relatively limited, i.e. $7 \%$ of the life cycle 
financial cost. When looking at the work sections, the asphalt layers and the electric and data cables contribute

329

330

331

332

333

334

335

336

337

338

339

340

341

342

343

344

345

346

347

348

349

350

351

352

353

354

355

356

357 most to the financial cost, with respectively $22 \%$ and $18 \%$ of the life cycle cost.

Fig. 8 here

Fig. 9 here

The comparison of the life cycle financial cost of the different surface layers (Road 1-Road 5) shows a quite different picture than for the environmental cost. The cobblestone surface layer has the highest financial cost, 210\% higher compared to the asphalt surface layer. This is due to the high market price of reclaimed cobblestone and the high labour cost for laying these. Compared to asphalt, the concrete surface layer has a 7\% lower life cycle financial cost but this reduction is compensated by the higher demolition cost of concrete roads. The surface layers in non-permeable and permeable concrete paving stones are respectively $30 \%$ and $14 \%$ less expensive than the asphalt surface layer, due to a lower maintenance and replacement cost. However, for the permeable concrete stones, the lower financial cost of the surface layer is compensated by an increase in the cost of the road base, consisting of porous lean concrete instead of cement bonded crushed rubble.

The analysis of the alternatives for the type of base, sub-base and sewerage system (Road 6-Road 8), reveals that using a gravel base and sub-base results in an increase of $28 \%$ of the financial cost of those work sections. Another type of sewerage (PVC or PP pipes) leads to a small change in the financial cost of the sewer pipes, of respectively $+4 \%$, and $-5 \%$.

As for the environmental cost, differences in total financial cost between the analysed road sections are quite small, i.e. about $1 \%$, compared to the asphalt road. Only the cobblestone road and the road in non-permeable concrete paving stones show bigger differences with financial cost of respectively $+25 \%$ and $-7 \%$, compared to the asphalt variant.

Based on the life cycle financial and environmental cost, the total cost of the road sections is calculated (Electronic supplementary material Fig. S.9). The results show a similar picture as for the financial cost because the environmental cost (calculated based on the median scenario) only represents about $10 \%$ of the total cost.

\subsubsection{LCA and LCC of bicycle paths}

The results of the environmental impact assessment of the bicycle paths are shown in the Electronic supplementary material, Fig. S.10 and Table S.7. Large differences in environmental cost are found between the bicycle paths analysed (Fig. S.10). When considering uncoloured bicycle paths (Bicycle path 1-Bicycle path 5), the asphalt bicycle path causes the highest life cycle environmental impact due to a higher replacement frequency. Bicycle paths consisting of concrete, concrete paving stones and concrete tiles cause an environmental cost which is 
respectively $11 \%, 7 \%$ and $35 \%$ lower than the environmental cost of an asphalt bicycle path, while permeable concrete paving stones have a similar environmental cost. The analysis of the red coloured bicycle paths (Bicycle path 6-Bicycle path 9) reveals that using red pigments in concrete and concrete paving stones results in a negligible increase in environmental cost of approximately $1 \%$. Road marking has a major impact as the results show a $44 \%$ higher environmental cost for a bicycle path with red road paint and an increase of $192 \%$ when using red cold plastic coating, compared to an uncoloured asphalt bicycle path. Despite the higher replacement frequency of road paint ( 1 year versus 3 year), the environmental impact of a bicycle path with a cold plastic coating is $103 \%$ higher than for a bicycle path with road paint, due to a larger dosage $\left(3.35 \mathrm{~kg} / \mathrm{m}^{2}\right.$ versus $\left.0.7 \mathrm{~kg} / \mathrm{m}^{2}\right)$ and the production impact of the polymethyl methacrylate binder used in cold plastic coating.

The results of the financial assessment are slightly different (Electronic supplementary material, Fig. S.11). The bicycle paths of asphalt and a surface layer in permeable concrete stones have a similar financial cost. The other bicycle paths consisting of concrete result in a lower life cycle financial cost, ranging from a reduction of 6 to $21 \%$ compared to asphalt. The bicycle paths with road marking have a higher financial cost (i.e. up to $186 \%$ higher compared to the uncoloured paths) due to the high frequency of repainting and recoating.

\subsubsection{LCA of roads including car traffic}

As mentioned in the introduction, the environmental impact of traffic during the use phase can be much higher than the environmental impact of the road. Different studies focused on the effect of pavement properties on rolling resistance which influences the vehicle fuel consumption (Willis et al. 2014). In this paper an estimation of the impact of the surface layer on the fuel consumption is made for the concrete and cobblestone road (Fig. 10). (Descornet 1990) pointed out that for a surface layer in cobblestones an increase in fuel consumption of 9\%, compared to concrete, is possible. This estimation is used in our analysis. Two scenarios for the traffic load are analysed: the first scenario considers a low traffic load of 100 vehicles per day, the second scenario considers a more intensive traffic load of 1000 vehicles per day. Although a higher traffic load could increase the damage to the road surface layers, the same maintenance and replacement scenarios, as defined in Table 4, are assumed, due to a lack of information in the literature. To evaluate the impact of traffic, an average passenger car is selected from the Ecoinvent database. In this record the processes related to the vehicle operation are adapted to account for an increase of 9\% in fuel consumption. Furthermore, the processes related to the road infrastructure, included in the environmental load per person-km in the Ecoinvent inventory records, are excluded to avoid double counting. In the scenario of 100 vehicles per day the impact of car traffic is about $1 / 4$ and $1 / 3$ of the life cycle environmental impact of the concrete and cobblestone road respectively. In the scenario of 1000 vehicles per day 
the impact of car traffic is respectively 2.5 and 3 times bigger. When including the impact of car traffic in the life cycle impact of the road sections, the cobblestone road has an $11 \%$ lower environmental impact in the first scenario but a similar environmental impact to the concrete road in the second scenario. This confirms the importance of considering the impact of car traffic when comparing road sections with different surface layers.

Fig. 10 here

\subsection{Assessment of the neighbourhood models}

The life cycle financial and environmental costs of the four neighbourhood models, over 60 years and expressed in euro $/ \mathrm{m}^{2}$ floor area, are shown in Fig. 11. A large variation between the different models is noticed: the total life cycle cost of the model with terraced houses is about $27 \%$ lower than of the model with detached houses. Compared to the model with terraced houses, the model consisting of apartments has a slightly higher total cost due to the impact of collective spaces, such as stairs and technical rooms, which is allocated to the different dwellings. The contribution of the road infrastructure to the total life cycle financial cost depends on the neighbourhood density, from $2 \%$ in the model with apartments to $8 \%$ in the model with detached houses. The results of the life cycle environmental cost show the same trends, although the contribution of the road infrastructure to the life cycle environmental cost is much higher, from $5 \%$ in the model with apartments to $21 \%$ in the model with detached houses.

Fig. 11 here

\section{Conclusions and recommendations}

In this paper the financial and environmental impact of road infrastructure in neighbourhoods are assessed, based on an integrated life cycle approach, combining LCC and LCA. The hierarchical structure of the element method for cost control is applied, enabling an analysis at various scale levels, i.e. from building materials, work sections, building elements, buildings to neighbourhoods.

The methodology is illustrated by analysing various sections for local roads. The environmental impact assessment shows the importance of the production phase, which contributes to about $50 \%$ of the life cycle environmental cost. The high influence of the production phase was also concluded in (Mroueh et al. 2001; Weiland 2008; Gschösser 2011). Other main contributors are the energy use for road lighting, replacement of work sections and transport to the site. Among the work sections, the surface layer causes a high impact, with a contribution in most road sections of about $20 \%$ of the life cycle environmental cost. Therefore the selection of environmental friendly surfacing materials and the optimisation of their maintenance and replacement scenarios are important parameters to reduce the environmental impact of road infrastructure. The significant role of the maintenance and replacement 
processes was also pointed out in (Gschösser 2011; Giustozzi et al. 2012; Jullien et al. 2014). Moreover, all piped and electrical services contribute to about $50-60 \%$ of the life cycle environmental cost, mainly due to the high impact of electric cables. The analysis of the environmental impact of neighbourhood infrastructure should therefore include those work sections. As mentioned in the literature (Häkkinen and Mäkelä 1996; Weiland 2008; Gschösser 2011), preferences between the pavement types analysed are influenced by the environmental impact indicators considered. Therefore the use of an aggregated indicator, such as the environmental cost, is recommended to support decision taking. The same recommendation concerning the use of weighting instead of single impact indicators was formulated by (Kägi et al. 2016).

Similar conclusions can be drawn for the financial cost. The investment is the main contributor, i.e. about $60-65 \%$ of the life cycle financial costs, and is followed by the replacement of work sections. Among the work sections, the surface layer causes a high cost, i.e. about $15-35 \%$ of the life cycle financial cost. The piped and electrical services jointly contribute to about $45-60 \%$ of the life cycle financial cost. Despite these similarities, it is identified that preferences between the road sections based on the financial cost differ importantly from those based on the environmental cost. For example, the road with reclaimed cobblestone pavement has the highest financial cost but the lowest environmental impact.

As concluded in (Descornet 1990; Stripple 2001; Mroueh et al. 2001), the analysis of the environmental impact of car traffic during the use phase shows the significant contribution of this process, varying from about 1/4 of the impact of the road for a traffic load of 100 vehicles per day to about 3 times the impact of the road for a traffic load of 1000 vehicles per day. For more intensive traffic loads, the impact of the pavement rolling resistance on the traffic fuel consumption should be considered when comparing road sections with different surface layers. This is in line with the recommendations formulated by (Santero et al. 2010; Carlson 2011).

The comparison of four neighbourhood models highlights the importance of the neighbourhood layout and built density with differences in total cost per $\mathrm{m}^{2}$ floor of more than $25 \%$ between the models analysed. The contribution of the road infrastructure to the total (i.e. sum of the environmental and financial) life cycle cost is relatively limited compared to the buildings. However the road infrastructure can contribute up to about $20 \%$ to the life cycle environmental cost and up to about $8 \%$ to the life cycle financial cost in low built density neighbourhoods. Based on this analysis, it can be concluded that spatial planning significantly influences the financial and environmental impact of neighbourhoods. The design of denser neighbourhood layouts can be one of the key parameters to reduce the amount of required infrastructure and to improve the sustainability of the built environment. 


\section{References}

Allacker K (2010) Sustainable building, The development of an evaluation method. PhD dissertation, KU Leuven

Allacker K, Debacker W, Delem L, De Nocker L, De Troyer F, Janssen A, Peeters K, Servaes R, Spirinckx C, Van Dessel J (2013a) Environmental profile of building elements. OVAM, Mechelen

Allacker K, De Troyer F, Trigaux D, Geerken T, Debacker W, Spirinckx C, Van Dessel J, Janssen A, Delem L, Putzeys K (2013b) SuFiQuaD: Sustainability, Financial and Quality Evaluation of Dwelling types. Belgian Science Policy (BELSPO), Brussels

Araújo JPC, Oliveira JRM, Silva HMRD (2014) The importance of the use phase on the LCA of environmentally friendly solutions for asphalt road pavements. Transp Res Part Transp Environ 32:97-110. doi: 10.1016/j.trd.2014.07.006

ASPEN (ed) (2008a) ASPENINDEX - Nieuwbouw (translated title: ASPENINDEX - New construction). Antwerpen

ASPEN (ed) (2008b) ASPENINDEX - Ombouw (translated title: ASPENINDEX - Renovation). Antwerpen

Butt AA (2012) Life Cycle Assessment of Asphalt Pavements including the Feedstock Energy and Asphalt Additives. Licentiate thesis, KTH, Royal Institute of Technology

Carlson A (2011) Life cycle assessment of roads and pavements - Studies made in Europe. VTI, Linköping, Sweden

CEN (ed) (2011) EN 15978 Sustainability assessment of construction works - assessment of environmental performance of buildings - calculation method.

CEN (ed) (2013) EN 15804:2012+A1 Sustainability of construction works - Environmental product declaration Core rules for the product category of construction products.

Descornet G (1990) Influence des caractéristiques de surface sur la résistance au roulement et à la consommation de carburant. Road Surface Influence on Tyre Rolling Resistance. In: Meyer W, Reichert J (eds) Surface Characteristics of Roadways: International Research and Technologies. ASTM International STM 1031, Philadelphia, pp 401-415

De Troyer F (2008) BB/SfB-plus. Een functionele hiërarchie van gebouwelementen (translated title: BB/SfB-plus. A functional hierarchy of building elements). Acco Uitgeverij, Leuven

De Troyer F, Neuckermans H, Havenne D, Simon F (1990) BB/SfB Tabellen 1990 (translated title: BB/SfB tables 1990). Regie der Gebouwen, Brussel

Ding T, Sun L, Chen Z (2013) Optimal Strategy of Pavement Preventive Maintenance Considering Life-Cycle Cost Analysis. Elsevier, Shenzhen,

EC-JRC (2011) International Reference Life Cycle Data System (ILCD) Handbook - Recommendations based on existing environmental impact assessment models and factors for Life Cycle Assessment in a European context. Joint Research Centre (JRC) of European Commission - Institute for Environment and Sustainability (IES)

Egyed CE., Visser H, Tromp E (2008) Inventarisatie ondergrondse infrastructuur, Duurzame Onderhoudsstrategie voor voorzieningen op "slappe bodem.” Arcadis, Delft

European Environment Agency (2006) Urban sprawl in Europe, the ignored challenge. European Environment Agency, Copenhagen, Denmark

FHWA (2011) LCCA software RealCost v2.5. http://www.fhwa.dot.gov/infrastructure/asstmgmt/lccasoft.cfm. Accessed 6 Jul 2015 
Frischknecht R, Jungbluth N, Althaus H, Doka G, Dones R, Hischier R, Hellweg S, Nemecek T, Rebitzer G, Spielmann M (2007) Overview and Methodology - Final report ecoinvent data v2.0, No. 1. ecoinvent Centre, Dübendorf

Giustozzi F, Crispino M, Flintsch G (2012) Multi-attribute life cycle assessment of preventive maintenance treatments on road pavements for achieving environmental sustainability. Int J Life Cycle Assess 17:409_ 419. doi: 10.1007/s11367-011-0375-6

Gschösser F (2011) Environmental Assessment of Road Constructions, Life Cycle Assessment of Swiss Road Pavements and an Accompanying Analysis of Construction and Maintenance Costs. PhD dissertation, ETH Zurich

Häkkinen T, Mäkelä K (1996) Environmental adaption of concrete. Environmental impact of concrete and asphalt pavements. Espoo

Hoang T, Jullien A, Ventura A (2005) A global methodology for sutainable road. Application to the environmental assessment of French highway. Lyon, France,

Holt A, Sullivan S, Hein D (2011) Life Cycle Cost Analysis of Municipal Pavements in Southern and Eastern Ontario. Edmonton,

Huang Y, Spray A, Parry T (2013) Sensitivity analysis of methodological choices in road pavement LCA. Int J Life Cycle Assess 18:93-101. doi: 10.1007/s11367-012-0450-7

Jullien A, Dauvergne M, Cerezo V (2014) Environmental assessment of road construction and maintenance policies using LCA. Transp Res Part Transp Environ 29:56-65. doi: 10.1016/j.trd.2014.03.006

Kägi T, Dinkel F, Frischknecht R, Humbert S, Lindberg J, De Mester S, Ponsioen T, Sala S, Schenker UW (2016) Session “Midpoint, endpoint or single score for decision-making?"-SETAC Europe 25th Annual Meeting, May 5th, 2015. Int J Life Cycle Assess 21:129-132. doi: 10.1007/s11367-015-0998-0

Mroueh U-M, Eskola P, Laine-Ylijoki J (2001) Life-cycle impacts of the use of industrial by-products in road and earth construction. Waste Manag 21:271-277. doi: 10.1016/S0956-053X(00)00100-8

Noshadravan A, Wildnauer M, Gregory J, Kirchain R (2013) Comparative pavement life cycle assessment with parameter uncertainty. Transp Res Part Transp Environ 25:131-138. doi: 10.1016/j.trd.2013.10.002

Oosterom E, Hermans R (2013) Riolering in beeld, Benchmark rioleringszorg. Stichting Rioned

Rangaraju PR, Amirkhanian S, Guven Z (2008) Life Cycle Cost Analysis for Pavement Type Selection. Departement of Civil Engineering, Clemson University, Columbia

Ray-Jones A, Clegg D (1978) CI/SfB Construction Indexing Manual. RIBA Publications Ltd, London

Santero NJ, Masanet E, Horvath A (2011) Life-cycle assessment of pavements. Part I: Critical review. Resour Conserv Recycl 55:801-809. doi: 10.1016/j.resconrec.2011.03.010

Santero NJ, Masanet E, Horvath A (2010) Life Cycle Assessment of Pavements: A Critical Review of Existing Literature and Research. Skokie, Illinois, USA

Scheving AG (2011) Life Cycle Cost Analysis of Asphalt and Concrete Pavements. Master thesis, Reykjavik University

Spon press (ed) (2015a) Spon’s External Works and Landschape Price Book 2015, 34th edition. AECOM, London

Spon press (ed) (2015b) Spon’s Civil Engineering and Highway Works Price Book 2015, 29th edition. AECOM, London

Stripple H (2001) Life Cycle Assessment of Road: a Pilot Study for Inventory Analysis. IVL Swedish Environmental Research Institute, Gothenburg, Sweden 
Trigaux D, Allacker K, De Troyer F (2014) Model for the environmental impact assessment of neighbourhoods. In: Passerini G, Brebia CA (eds) Environmental Impact II. WIT Press, Ancona, Italy, pp 103-114

Walls J, Smith MR (1998) Life-Cycle Cost Analysis in Pavement Design - In Search of Better Investment Decisions. Federal Highway Administration, Washington

Waterford County Council, National University of Ireland, Bentley Systems Europe, Brian P. Connor \& Associates Ltd., Statens Vag-Och Transportforskningsinstitut, Agencia Municipal de Energia do Seixal, Engivia, BPR Europe/Saunier et Associés, Centrum dopravniho vyzkumu, Ramboll, Colas Construction Ltd, Technical research centre of Finland (VTT) (2010) Energy Conservation in Road Pavement Design, Maintenance and Utilisation.

Weiland CD (2008) Life Cycle Assessment of Portland Cement Concrete Interstate Highway Rehabilitation and Replacement. Master thesis, University of Washington

Wijnants L (2014) Levenscyclusanalyse van weginfrastructuur in de context van residentiële wijken (translated title: Life Cycle Assessment of road infrastructure in the context of residential neighbourhoods). Master thesis, KU Leuven

Willis JR, Robbins MM, Thompson M (2014) Effects of Pavement Properties on Vehicular Rolling Resistance: A 
Financial costs

\begin{tabular}{lcc}
\hline Discount rate & $2 \%$ & $1 \%$ \\
Growth rate material & $0 \%$ & $0 \%$ \\
Growth rate labour & $1 \%$ & - \\
Growth rate energy & $2 \%$ & $0 \%$ \\
\hline
\end{tabular}

547 Table 1 Economic parameters applied for the financial and environmental costs (real rates above the inflation), 548 based on (Allacker et al. 2013b)

\section{CEN indicators}

Climate change

Ozone depletion

Terrestrial acidification

Eutrophication (freshwater and marine)

Photochemical oxidant formation

Abiotic depletion of non-fossil resources

Abiotic depletion of fossil resources

\section{CEN+ indicators}

Human toxicity, cancer and non-cancer effects

Particulate matter formation

Ionising radiation, human health

Ecotoxicity (terrestrial, freshwater and marine)

Land use: occupation (agricultural/forest and urban)

Land use: transformation (natural and tropical rain

forest)

Water depletion

549 Table 2 Overview of the environmental impact indicators used in the MMG LCA method. A distinction is made

550 between the CEN and CEN+ impact categories. Impact categories indicated in italic are not translated to

551 environmental costs, due to the lack of reliable monetary values in the literature.

\begin{tabular}{|c|c|c|c|c|}
\hline Variant name & Sub-base & Base & Surface layer & Sewer system \\
\hline Road 1_asphalt & \multirow{5}{*}{$\begin{array}{l}\text { Crushed mixed } \\
\text { rubble }\end{array}$} & \multirow{4}{*}{$\begin{array}{l}\text { Cement bound } \\
\text { base - crushed } \\
\text { concrete rubble }\end{array}$} & Asphalt & \multirow{6}{*}{$\begin{array}{l}\text { Sanitary water: } \\
\text { vitrified clay }\end{array}$} \\
\hline Road 2_concrete & & & Concrete & \\
\hline Road 3_cobblestones & & & $\begin{array}{l}\text { Porphyry } \\
\text { cobblestones }\end{array}$ & \\
\hline Road 4_concrete stones & & & $\begin{array}{l}\text { Concrete paving } \\
\text { stones }\end{array}$ & \\
\hline $\begin{array}{l}\text { Road 5_permeable } \\
\text { concrete stones }\end{array}$ & & $\begin{array}{l}\text { Porous lean } \\
\text { concrete }\end{array}$ & $\begin{array}{l}\text { Concrete paving } \\
\text { stones with } \\
\text { enlarged joints }\end{array}$ & \\
\hline $\begin{array}{l}\text { Road 6_asphalt_crushed } \\
\text { gravel }\end{array}$ & Crushed gravel & $\begin{array}{l}\text { Cement bound } \\
\text { base - crushed } \\
\text { gravel }\end{array}$ & Asphalt & \\
\hline $\begin{array}{l}\text { Road 7_asphalt_PVC } \\
\text { sewer }\end{array}$ & \multirow{2}{*}{$\begin{array}{l}\text { Crushed mixed } \\
\text { rubble }\end{array}$} & \multirow{2}{*}{$\begin{array}{l}\text { Cement bound } \\
\text { base - crushed } \\
\text { concrete rubble }\end{array}$} & Asphalt & PVC \\
\hline $\begin{array}{l}\text { Road 8_asphalt_PP } \\
\text { sewer }\end{array}$ & & & Asphalt & $\mathrm{PP}$ \\
\hline
\end{tabular}

552 Table 3 Composition of the road sections analysed.

Work sections

Maintenance

Replacement

\begin{tabular}{llrr}
\hline Surface layer & Asphalt & 5\% repair of asphalt top layer - 5 year & 30 year \\
& Concrete & Fissure filling and 0.1\% repair - 10 year & 40 year \\
& Cobblestones & Relay - 20 year & 40 year \\
& Concrete tiles & Relay and 10\% new tiles - 20 year & 40 year \\
& Concrete paving stones & Relay and 10\% new stones - 20 year & 1 year \\
Road marking & Solvent paint & & 3 year
\end{tabular}


Electrical services Lighting column

Lighting lantern

Data cable
40 year

20 year

20 year
553

554

555

Table 4 Maintenance and replacement scenarios, applied to the analysed roads and bicycle paths, based on data from (Wijnants 2014) 

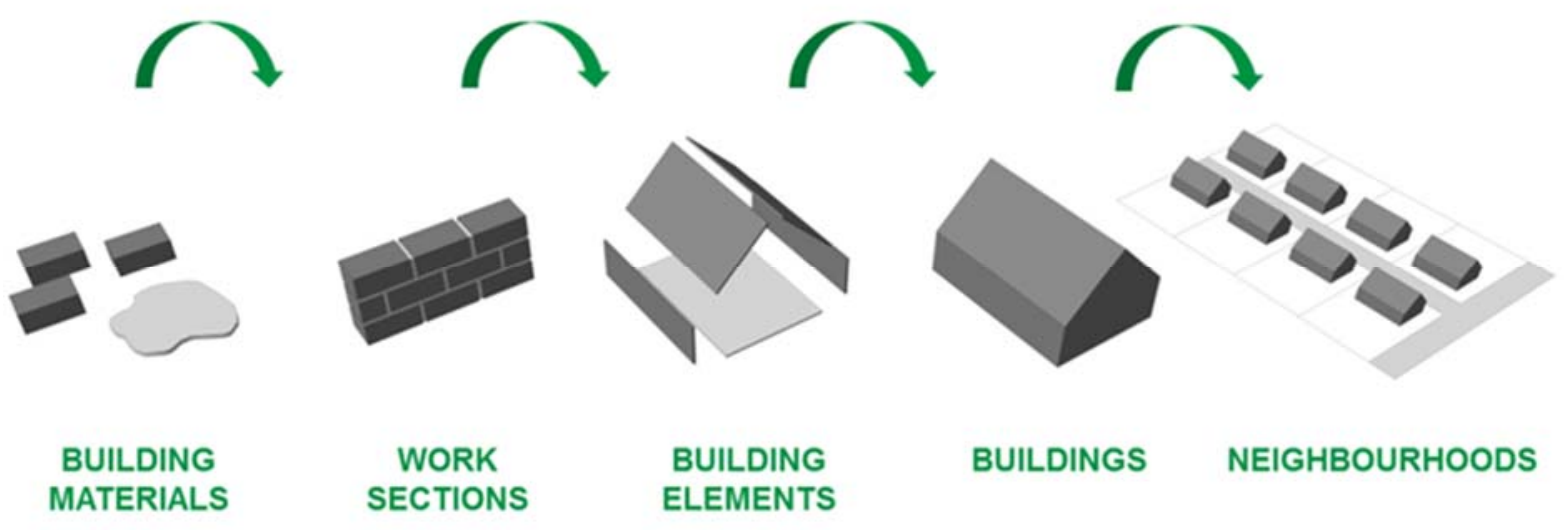

\section{SECTIONS}

\section{ELEMENTS}

Fig. 1 Element method for cost control and scale levels (Trigaux et al. 2014)

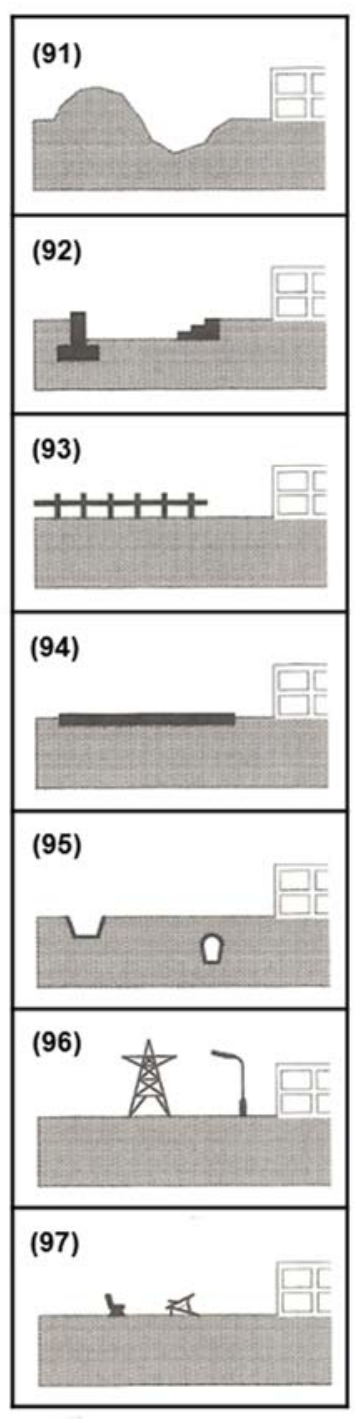

(91) GROUND PREPARATION

examples: ground clearing, shaping

(92) MINOR STRUCTURE

examples: shelters, sheds

(93) ENCLOSURES

examples: fences, gates

(94) GROUND SURFACE TREATMENTS

examples: roads, squares, green areas

(95) PIPED SERVICES

examples: sewer, district heating

(96) ELECTRICAL SERVICES

examples: outdoor lighting

(97) FITTINGS

examples: hoardings, outdoor benches

Fig. 2 BB/SfB-plus classification for external works (9-) (De Troyer 2008) 


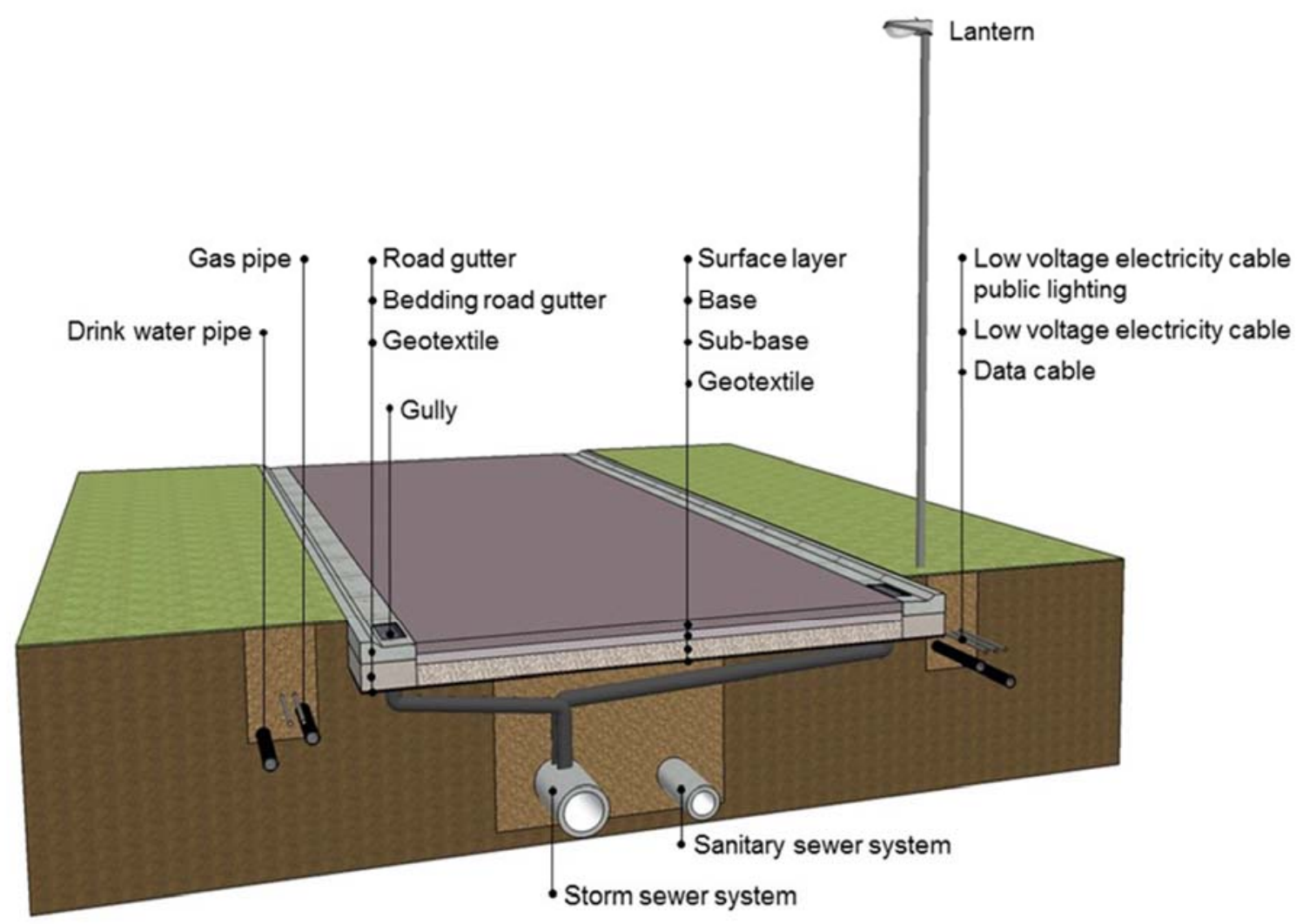

Fig. 3 3D section of the road sections analysed

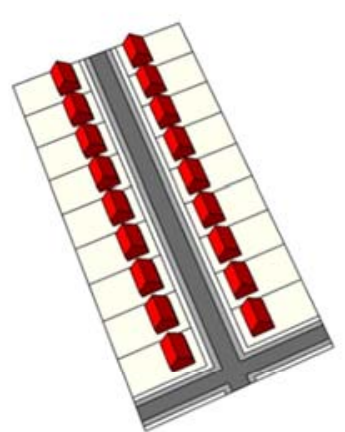

Model 1_detached Floor Space Index $=0.21$

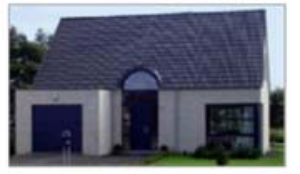

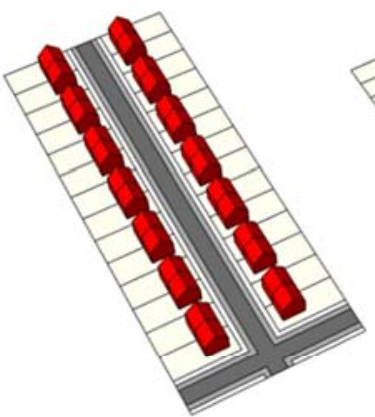

Model 2_semidetached Floor Space Index $=0.39$

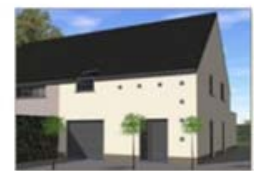

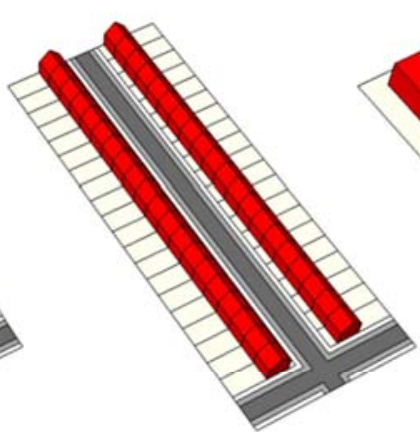

Model 3_terraced Floor Space Index $=0.76$

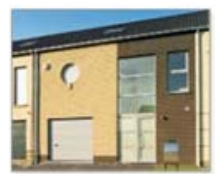

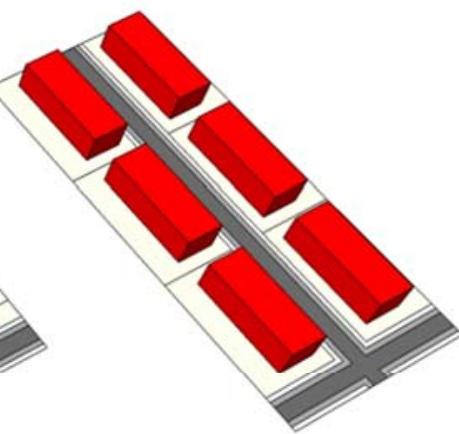

Model 4_apartments Floor Space Index $=1.13$

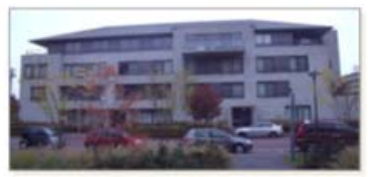

Fig. 4 Neighbourhood models based on four representative dwelling typologies for the Belgian context: detached houses (Model 1), semi-detached houses (Model 2), terraced houses (Model 3) and apartments (Model 4) 


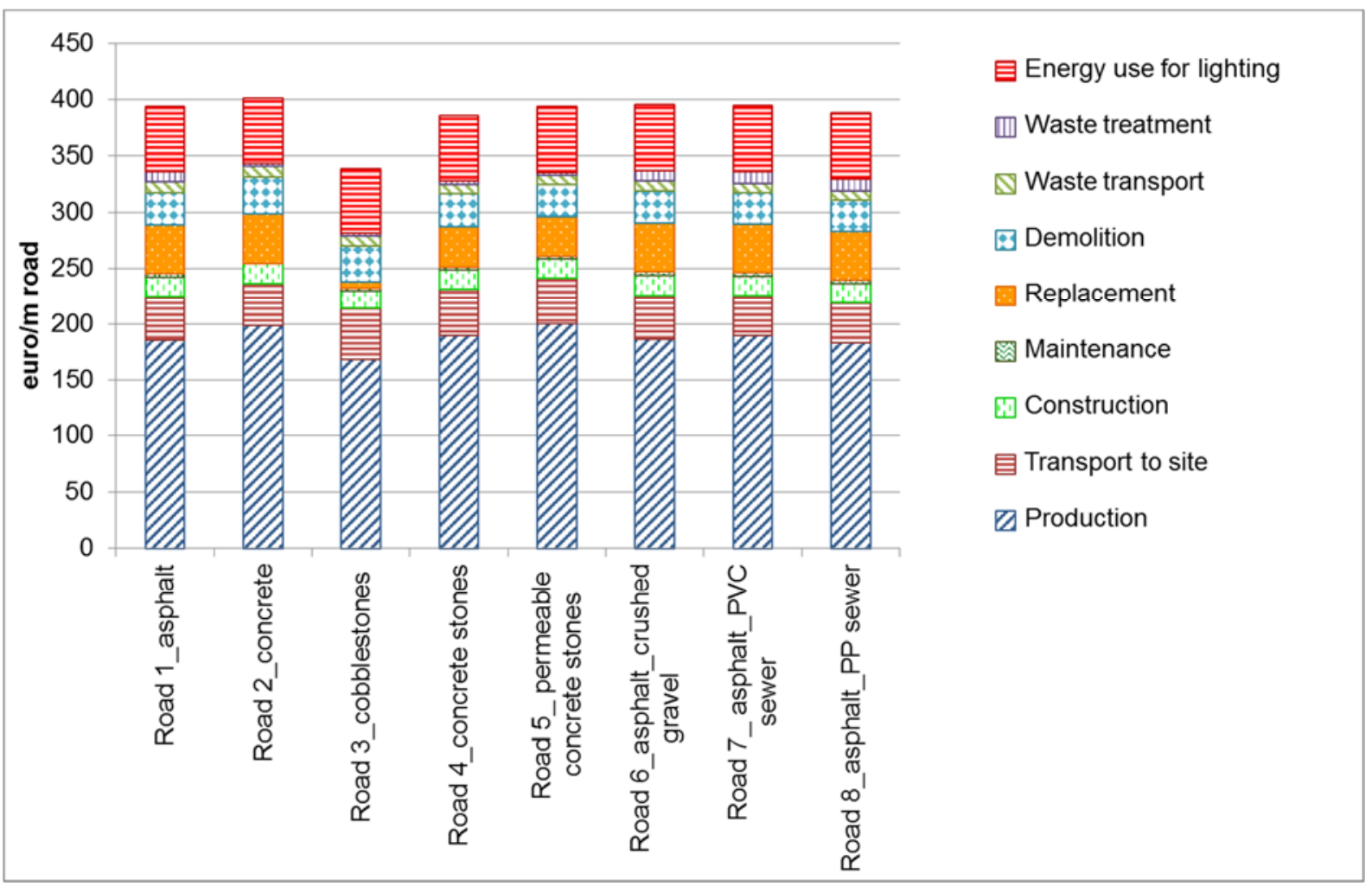

568 Fig. 5 Life cycle environmental cost (median scenario) of the road sections analysed, subdivided per life cycle 569 phase

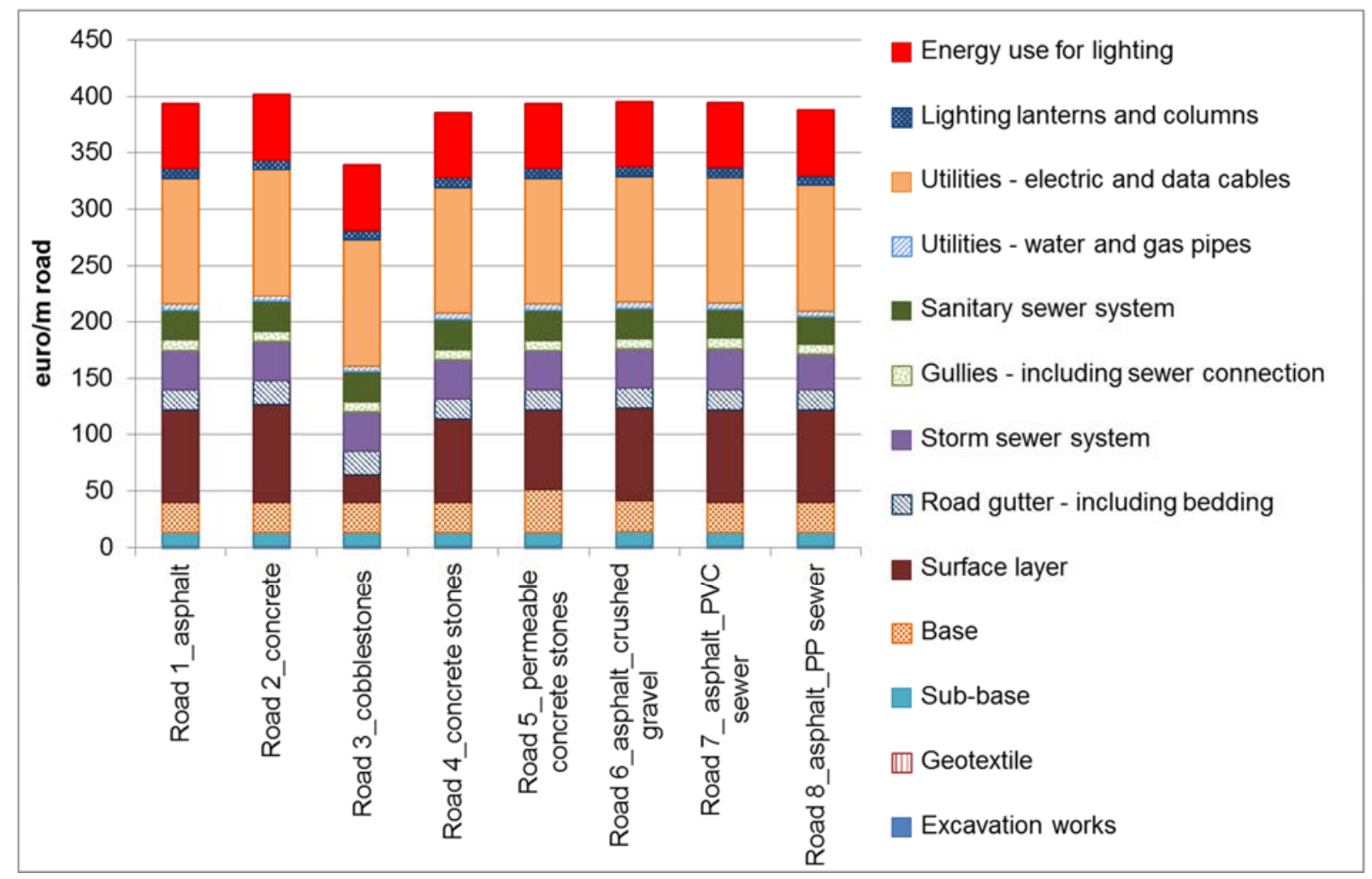

571 Fig. 6 Life cycle environmental cost (median scenario) of the road sections analysed, subdivided per work section 


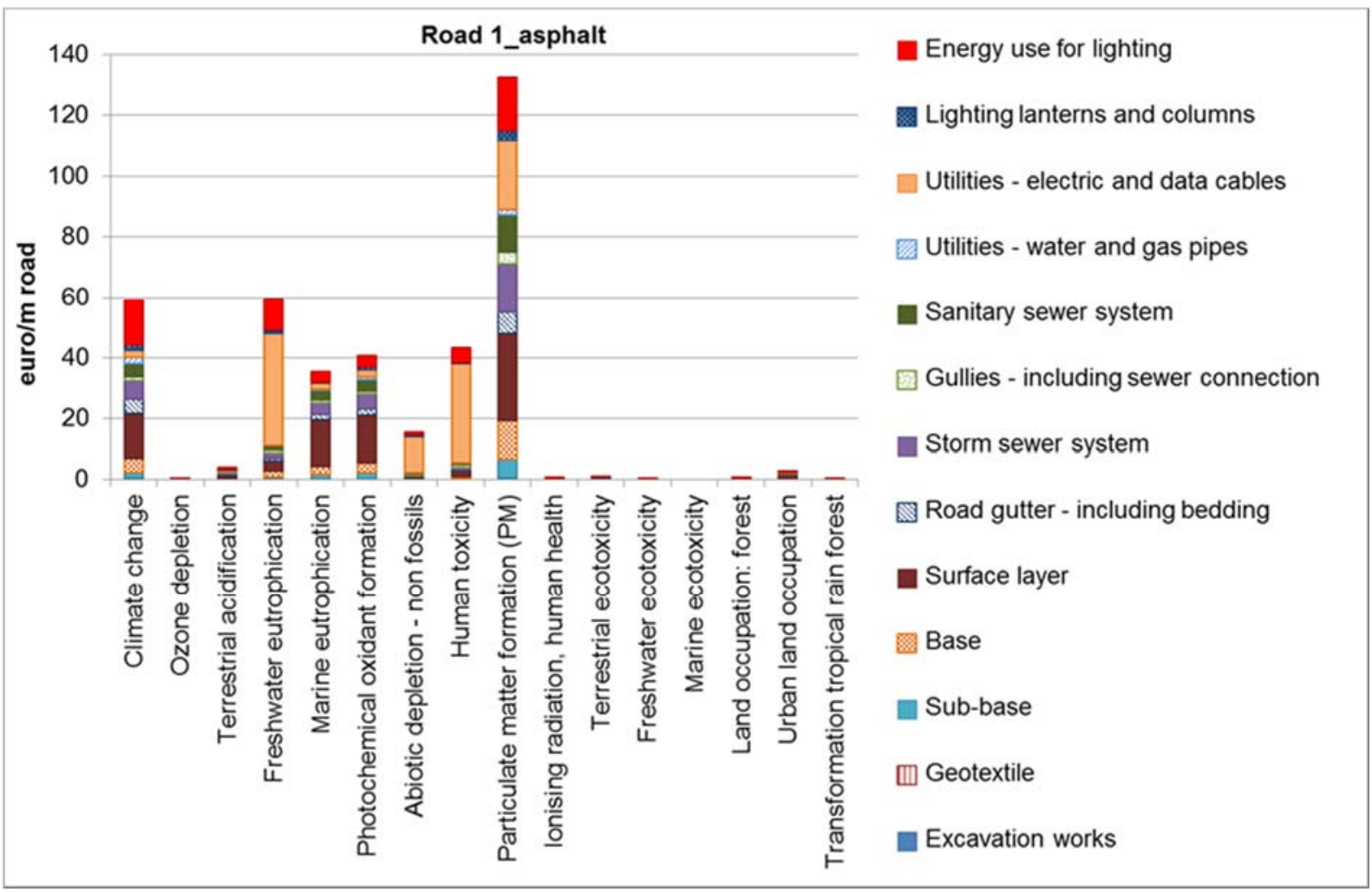

573 Fig. 7 Life cycle environmental cost (median scenario) of the asphalt road section, subdivided per impact category and work section

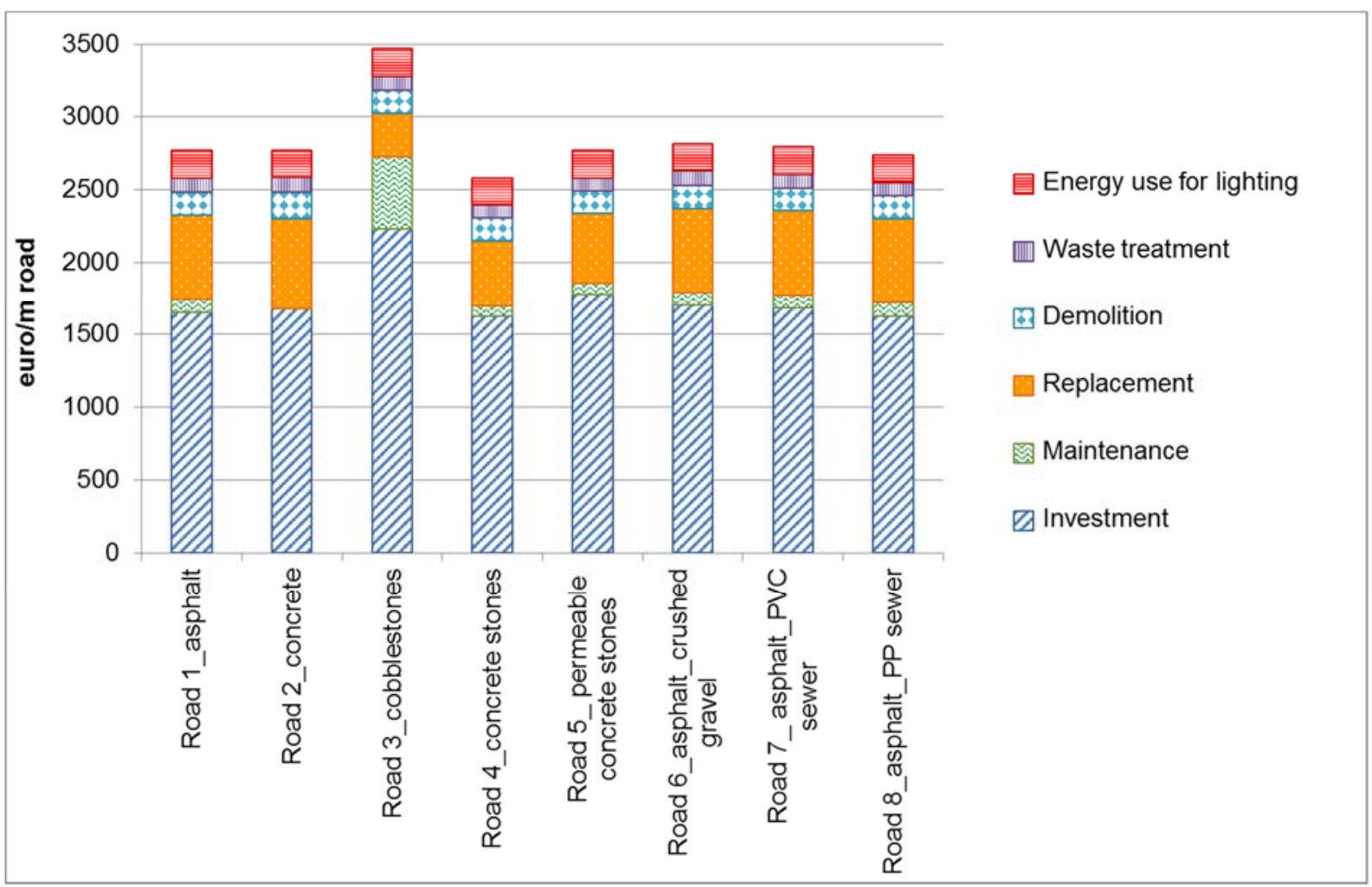

Fig. 8 Life cycle financial cost of the road sections analysed, subdivided per life cycle phase 


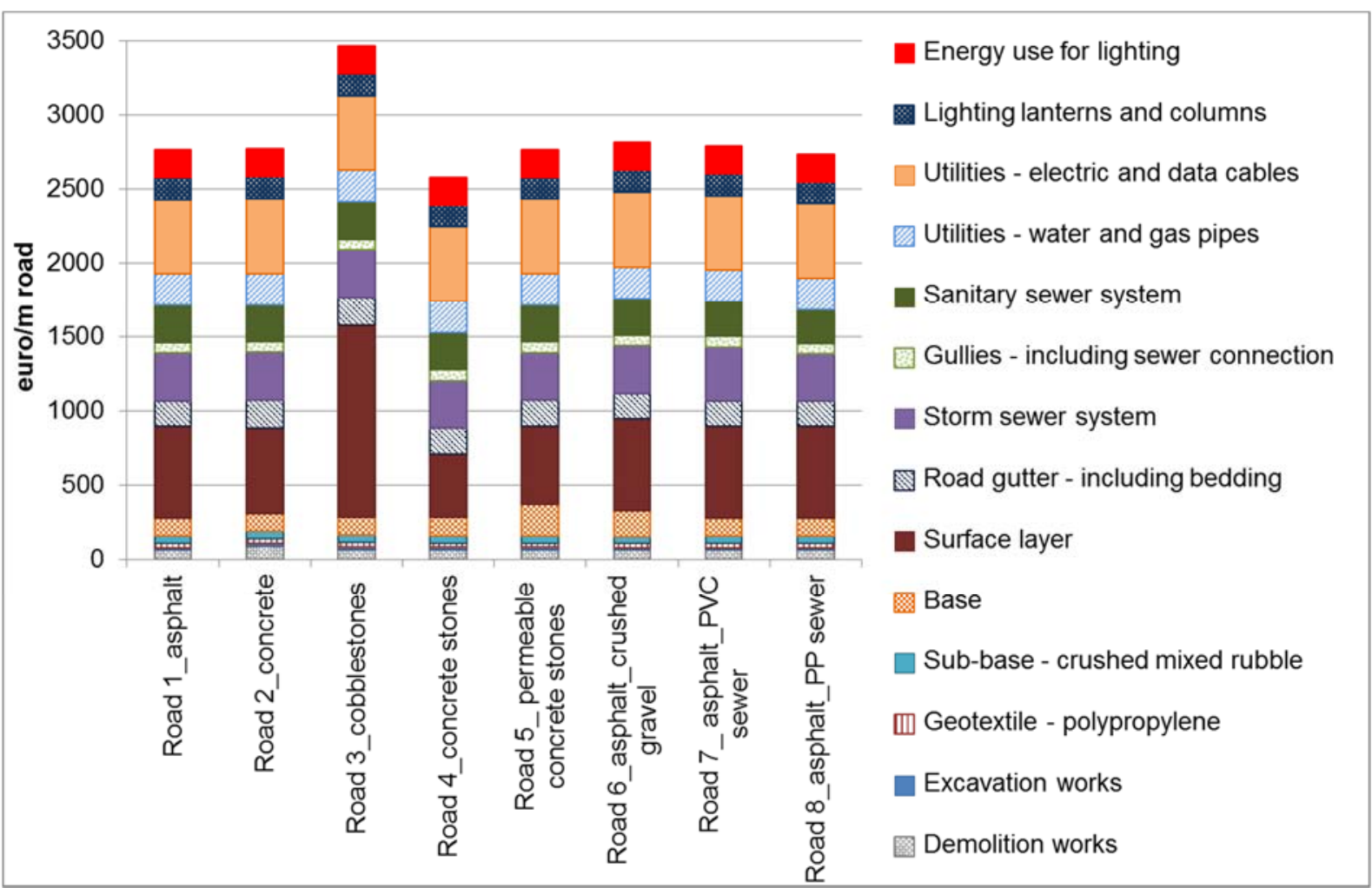

579 Fig. 9 Life cycle financial cost of the road sections analysed, subdivided per work section

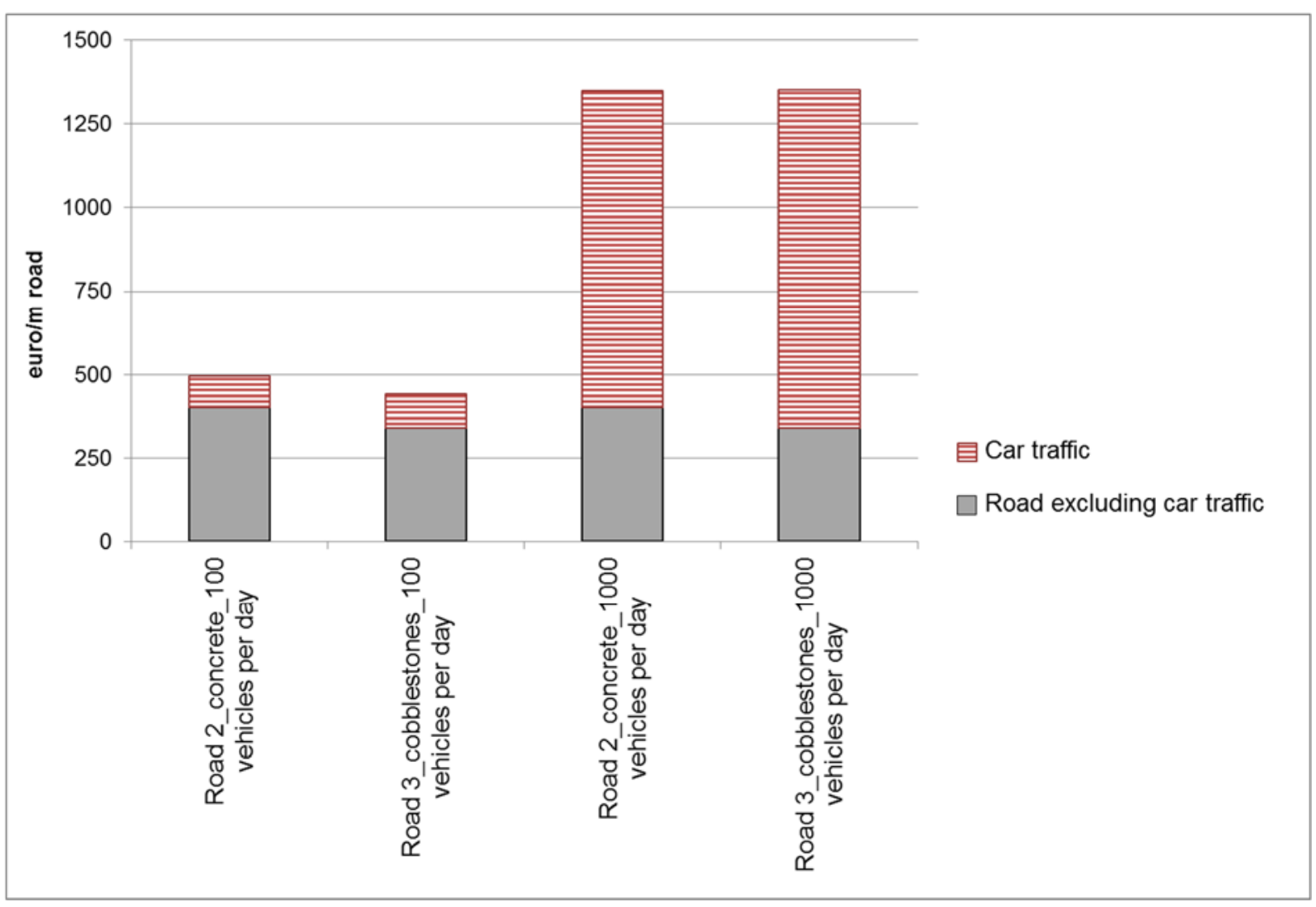

581 Fig. 10 Life cycle environmental cost (median scenario) of a concrete and cobblestone road, including the impact of car traffic for a traffic load of 100 and 1000 vehicles per day. 


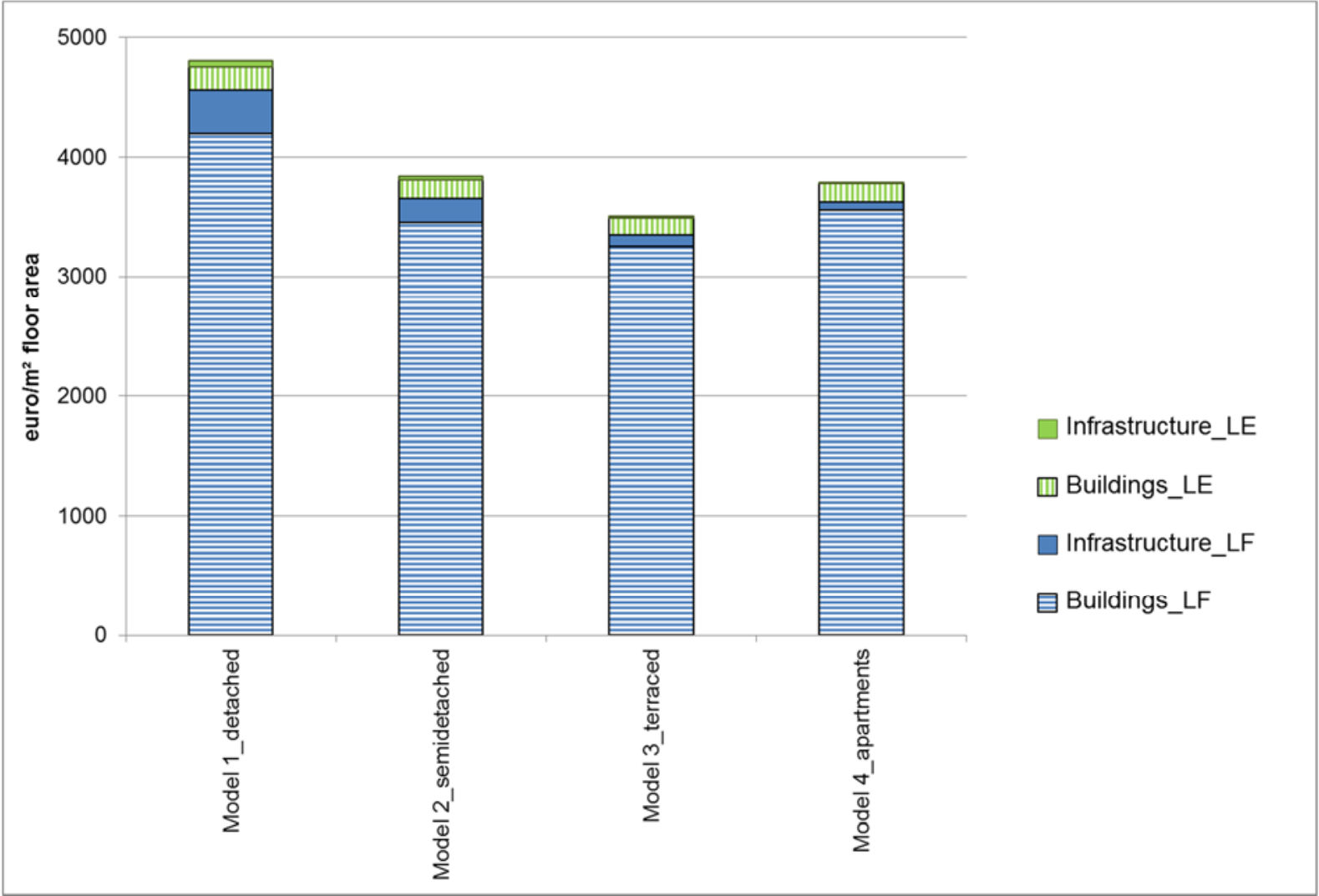

Fig. 11 Life cycle environmental (LE) and financial cost (LF) of the neighbourhood models analysed, subdivided in building and infrastructure cost 
2 Tables

\begin{tabular}{|c|c|c|c|c|}
\hline CEN indicators & Unit & $\begin{array}{l}\text { Median } \\
\text { (€/unit) }\end{array}$ & $\begin{array}{l}\text { Minimum } \\
\text { (€/unit) }\end{array}$ & $\begin{array}{l}\text { Maximum } \\
\text { (€/unit) }\end{array}$ \\
\hline Climate change & $\mathrm{kg} \mathrm{CO} 2 \mathrm{eq}$ & 0.06 & 0.012 & 0.3 \\
\hline Ozone depletion & kg CFC-11 eq & 49.1 & 12.3 & 196.3 \\
\hline Terrestrial acidification & $\mathrm{kg} \mathrm{SO} 2 \mathrm{eq}$ & 0.85 & 0.21 & 3.4 \\
\hline Freshwater eutrophication & $\mathrm{kg} P$ eq & 100 & 20 & 500 \\
\hline Marine eutrophication & kg N eq & 18 & 3.6 & 90 \\
\hline Photochemical oxidant formation & $\begin{array}{l}\text { kg NMVOC } \\
\text { eq }\end{array}$ & 7.4 & 1.85 & 29.6 \\
\hline Abiotic depletion of non-fossil resources & kg Fe eq & 0.052 & 0.0104 & 0.26 \\
\hline Abiotic depletion of fossil resources & kg oil eq & 0 & 0 & 0 \\
\hline
\end{tabular}

3 Table S. 1 Overview of the monetary values (median, minimum and maximum scenarios) for the CEN indicators

4 (Allacker et al. 2013a)

\begin{tabular}{|c|c|c|c|c|}
\hline CEN+ indicators & Unit & $\begin{array}{l}\text { Median } \\
\text { (€/unit) }\end{array}$ & $\begin{array}{l}\text { Minimum } \\
\text { (€/unit) }\end{array}$ & $\begin{array}{l}\text { Maximum } \\
\text { (€/unit) }\end{array}$ \\
\hline $\begin{array}{l}\text { Human toxicity, cancer and non-cancer } \\
\text { effects }\end{array}$ & DALY & 60000 & 15000 & 240000 \\
\hline Particulate matter formation & DALY & 60000 & 20000 & 180000 \\
\hline Ionising radiation, human health & DALY & 60000 & 15000 & 240000 \\
\hline Terrestrial ecotoxicity & kg 1,4-DB eq & 4.31 & 1.078 & 17.24 \\
\hline Freshwater ecotoxicity & kg 1,4-DB eq & 0.019 & 0.00475 & 0.076 \\
\hline Marine ecotoxicity & kg 1,4-DB eq & $1.4 \mathrm{E}-06$ & 3.5E-07 & 5.6E-06 \\
\hline Land use: occupation - agricultural/forest & $\mathrm{m}^{2} \mathrm{a}$ & 0.036 & 0.007 & 0.182 \\
\hline Land use: occupation - urban & $m^{2} a$ & 0.181 & 0.036 & 0.907 \\
\hline $\begin{array}{l}\text { Land use: transformation - natural } \\
\text { (except tropical rain forest) }\end{array}$ & $\mathrm{m}^{2}$ & 1 & 1 & 1 \\
\hline $\begin{array}{l}\text { Land use: transformation - tropical rain } \\
\text { forest }\end{array}$ & $\mathrm{m}^{2}$ & 0.8 & 0.16 & 4 \\
\hline Water depletion & $\mathrm{m}^{3}$ & / & / & 1 \\
\hline
\end{tabular}

5 Table S. 2 Overview of the monetary values (median, minimum and maximum scenarios) for the CEN+ indicators

6 (Allacker et al. 2013a). Impact categories indicated in italic are not translated to environmental costs, due to the

7 lack of reliable monetary values in the literature. 


\begin{tabular}{|c|c|c|c|c|c|c|c|c|}
\hline & $\begin{array}{l}\text { Road 1__ } \\
\text { asphalt }\end{array}$ & $\begin{array}{l}\text { Road 2_- } \\
\text { concrete }\end{array}$ & $\begin{array}{c}\text { Road 3_} \\
\text { cobblestones }\end{array}$ & $\begin{array}{c}\text { Road 4_- } \\
\text { concrete } \\
\text { stones }\end{array}$ & $\begin{array}{c}\text { Road 5 } \\
\text { permeable } \\
\text { concrete stones }\end{array}$ & $\begin{array}{c}\text { Road 6_ } \\
\text { asphalt_crushed } \\
\text { gravel }\end{array}$ & $\begin{array}{l}\text { Road 7_- } \\
\text { asphalt_PVC } \\
\text { sewer }\end{array}$ & $\begin{array}{l}\text { Road 8_- } \\
\text { asphalt_PP } \\
\text { sewer }\end{array}$ \\
\hline Geotextile & \multicolumn{8}{|c|}{ Polypropylene } \\
\hline Sub-base & \multicolumn{5}{|c|}{ Crushed mixed rubble - type II $(10 \mathrm{~cm})$} & $\begin{array}{l}\text { Crushed gravel - } \\
\text { type II }(10 \mathrm{~cm})\end{array}$ & \multicolumn{2}{|c|}{$\begin{array}{l}\text { Crushed mixed rubble - type II } \\
\qquad(10 \mathrm{~cm})\end{array}$} \\
\hline Base & \multicolumn{4}{|c|}{ Cement bound base - crushed concrete rubble - type IIA $(20 \mathrm{~cm})$} & $\begin{array}{c}\text { Porous lean } \\
\text { concrete - } \\
\text { limestone } \\
(20 \mathrm{~cm})\end{array}$ & $\begin{array}{l}\text { Cement bound } \\
\text { base - crushed } \\
\text { gravel - type II } \\
(20 \mathrm{~cm})\end{array}$ & \multicolumn{2}{|c|}{$\begin{array}{l}\text { Cement bound base - crushed } \\
\text { concrete rubble - type IIA } \\
\qquad(20 \mathrm{~cm})\end{array}$} \\
\hline Surface layer & $\begin{array}{l}\text { Asphalt } \\
\text { (binder course } \\
6 \mathrm{~cm} \text {, surface } \\
\text { course } 4 \mathrm{~cm} \text { ) }\end{array}$ & $\begin{array}{l}\text { Concrete } \\
(20 \mathrm{~cm})\end{array}$ & $\begin{array}{c}\text { Porphyry } \\
\text { cobblestones } \\
\left(14^{*} 14^{*} 14 \mathrm{~cm}\right) \\
+ \text { Sand layer } \\
(7,5 \mathrm{~cm})\end{array}$ & $\begin{array}{c}\text { Concrete } \\
\text { paving stones } \\
\left(22^{*} 11^{*} 10 \mathrm{~cm}\right) \\
+ \text { Sand layer } \\
(3 \mathrm{~cm})\end{array}$ & $\begin{array}{c}\text { Concrete paving } \\
\text { stones } \\
(22 * 16,5 * 10 \mathrm{~cm}) \\
\text { with enlarged } \\
\text { joints + Gravel } \\
\text { layer }(3 \mathrm{~cm}) \\
\end{array}$ & \multicolumn{3}{|c|}{ Asphalt (binder course $6 \mathrm{~cm}$, surface course $4 \mathrm{~cm}$ ) } \\
\hline Storm sewer system & \multicolumn{6}{|c|}{ Concrete $(\varnothing$ 400mm) } & $\begin{array}{l}\text { PVC }(\varnothing \\
400 \mathrm{~mm})\end{array}$ & $\begin{array}{l}\text { Ribbed PP }(\varnothing \\
\quad 400 \mathrm{~mm})\end{array}$ \\
\hline $\begin{array}{l}\text { Road gutter and } \\
\text { gully }\end{array}$ & \multicolumn{8}{|c|}{$\begin{array}{c}\text { Concrete road gutter (type IIIE) + Bedding road gutter (lean concrete) + Cast iron gully + Connection to storm sewer system ( Sewer pipe PVC } \varnothing \\
160 \mathrm{~mm})\end{array}$} \\
\hline $\begin{array}{l}\text { Sanitary sewer } \\
\text { system }\end{array}$ & \multicolumn{6}{|c|}{ Vitrified clay (Ø 250mm) } & $\begin{array}{l}\text { PVC }(\varnothing \\
250 \mathrm{~mm})\end{array}$ & $\begin{array}{l}\text { Ribbed PP (Ø } \\
\text { 250mm) }\end{array}$ \\
\hline Road lighting & \multicolumn{8}{|c|}{ Low voltage electricity cable $\left(4 \times 25 \mathrm{~mm}^{2}+16 \mathrm{~mm}^{2}\right.$ ground wire $)+$ Lantern $70 \mathrm{~W}+$ Galvanised steel column } \\
\hline Electricity cable & \multicolumn{8}{|c|}{ Low voltage electricity cable EXAVB-F2 (4x70mm²) } \\
\hline Data cable & \multicolumn{8}{|c|}{ Fibre glass data cables $(\varnothing 14 \mathrm{~mm})$} \\
\hline Gas pipe & \multicolumn{8}{|c|}{ HDPE $(\varnothing 110 \mathrm{~mm})$} \\
\hline Drink water pipe & \multicolumn{8}{|c|}{ HDPE (Ø 110mm) } \\
\hline
\end{tabular}

Table S. 3 Detailed composition of the road sections analysed 


\begin{tabular}{|c|c|c|c|c|c|c|c|c|c|}
\hline & $\begin{array}{c}\text { Bicycle path } \\
\text { 1_asphalt }\end{array}$ & $\begin{array}{c}\text { Bicycle path } \\
\text { 2_concrete }\end{array}$ & $\begin{array}{l}\text { Bicycle path } \\
\text { 3_concrete } \\
\text { stones }\end{array}$ & $\begin{array}{c}\text { Bicycle path } \\
\text { 4_permeable } \\
\text { concrete } \\
\text { stones }\end{array}$ & $\begin{array}{c}\text { Bicycle path } \\
5 \text { concrete } \\
\text { tiles }\end{array}$ & $\begin{array}{c}\text { Bicycle path } \\
\text { 6_asphalt_re } \\
\text { d solvent } \\
\text { paint }\end{array}$ & $\begin{array}{c}\text { Bicycle path } \\
\text { 7_asphalt_re } \\
\text { d coldplastic } \\
\text { coating }\end{array}$ & $\begin{array}{c}\text { Bicycle path } \\
\text { 8_red } \\
\text { concrete }\end{array}$ & $\begin{array}{c}\text { Bicycle path } \\
\text { 9_red } \\
\text { concrete } \\
\text { stones }\end{array}$ \\
\hline Geotextile & \multicolumn{9}{|c|}{ Polypropylene } \\
\hline Base & \multicolumn{4}{|c|}{ Cement bound base - crushed concrete rubble - type IIA $(20 \mathrm{~cm})$} & $\begin{array}{c}\text { Porous lean } \\
\text { concrete - } \\
\text { limestone } \\
(20 \mathrm{~cm})\end{array}$ & \multicolumn{4}{|c|}{ Cement bound base - crushed concrete rubble - type IIA $(20 \mathrm{~cm})$} \\
\hline $\begin{array}{l}\text { Surface } \\
\text { layer }\end{array}$ & $\begin{array}{c}\text { Asphalt } \\
\text { (binder course } \\
6 \mathrm{~cm} \text {, surface } \\
\text { course } 4 \mathrm{~cm} \text { ) }\end{array}$ & $\begin{array}{c}\text { Concrete } \\
(16 \mathrm{~cm})\end{array}$ & $\begin{array}{c}\text { Concrete } \\
\text { paving stones } \\
\left(22 * 11^{*} 10 \mathrm{~cm}\right. \\
)+ \text { Sand layer } \\
(3 \mathrm{~cm})\end{array}$ & $\begin{array}{c}\text { Concrete } \\
\text { paving stones } \\
(22 * 16,5 * 10 \mathrm{c} \\
\text { m) with } \\
\text { enlarged } \\
\text { joints + } \\
\text { Gravel layer } \\
(3 \mathrm{~cm})\end{array}$ & $\begin{array}{c}\text { Concrete tiles } \\
(40 * 40 * 4 \mathrm{~cm}) \\
+ \text { Sand layer } \\
(3 \mathrm{~cm})\end{array}$ & $\begin{array}{c}\text { Asphalt } \\
\text { (binder course } \\
6 \mathrm{~cm} \text {, surface } \\
\text { course } 4 \mathrm{~cm} \text { ) + } \\
\text { red solvent } \\
\text { paint, } \\
\text { inclusive glass } \\
\text { beads }\end{array}$ & $\begin{array}{c}\text { Asphalt } \\
\text { (binder course } \\
6 \mathrm{~cm} \text {, surface } \\
\text { course } 4 \mathrm{~cm} \text { ) }+ \\
\text { red cold } \\
\text { plastic } \\
\text { coating, } \\
\text { inclusive glass } \\
\text { beads }\end{array}$ & $\begin{array}{l}\text { Red concrete } \\
\quad(16 \mathrm{~cm})\end{array}$ & $\begin{array}{c}\text { Concrete } \\
\text { paving stones } \\
\left(22 * 11^{*} 10 \mathrm{~cm}\right) \\
+ \text { Sand layer } \\
(3 \mathrm{~cm})\end{array}$ \\
\hline Kerbstone & \multicolumn{9}{|c|}{ Concrete kerbstone (type ID4) + Bedding kerbstone (lean concrete) } \\
\hline
\end{tabular}

Table S. 4 Detailed composition of the bicycle path sections analysed 


\begin{tabular}{|c|c|}
\hline Building element & Standard variant \\
\hline Floor on grade & concrete slab - 5 cm PUR foam - screed mix - fired clay tiles \\
\hline External wall & facing brick - hollow brick clay $-6 \mathrm{~cm}$ rockwool - gypsum plaster - acrylic paint \\
\hline Loadbearing internal wall & $\begin{array}{l}\text { acrylic paint - gypsum plaster - hollow brick } 14 \text { cm - gypsum plaster - acrylic } \\
\text { paint }\end{array}$ \\
\hline Non-bearing internal wall & $\begin{array}{l}\text { acrylic paint - plasterboard - metal stud + } 10 \mathrm{~cm} \text { glass wool - plasterboard - } \\
\text { acrylic paint }\end{array}$ \\
\hline Floor & $\begin{array}{l}\text { acrylic paint - gypsum plaster - concrete slab } 15 \mathrm{~cm} \text { - screed mix - fired earth } \\
\text { tiles }\end{array}$ \\
\hline Stairs & wooden open staircase - varnish - wooden banister \\
\hline Flat roof & $\begin{array}{l}\text { EPDM - } 10 \mathrm{~cm} \text { PUR - concrete slope layer - concrete slab } 15 \mathrm{~cm} \text { - gypsum } \\
\text { plaster - acrylic paint }\end{array}$ \\
\hline Pitched roof & $\begin{array}{l}\text { Clay tiles - wood fibre board - purlins and jack rafters }+18 \mathrm{~cm} \text { rockwool - } \\
\text { plasterboard - acrylic paint }\end{array}$ \\
\hline Window & PVC frame - standard double-glazed $\left(\mathrm{U}=1.1 \mathrm{~W} / \mathrm{m}^{2} \mathrm{~K}\right)$ \\
\hline Internal door & MDF frame - plain door \\
\hline
\end{tabular}

11 Table S. 5 Overview of the building elements analysed (Trigaux et al 2014) 


\begin{tabular}{|c|c|c|c|c|c|c|c|c|}
\hline Impact category & 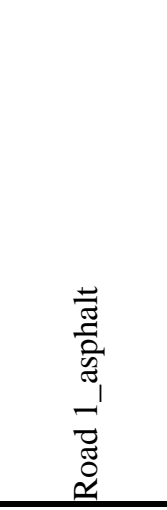 & 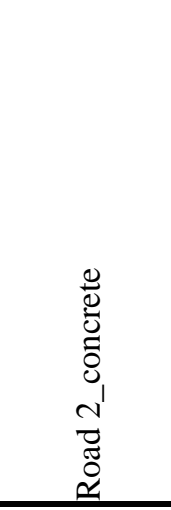 & 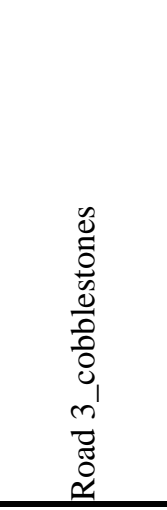 & 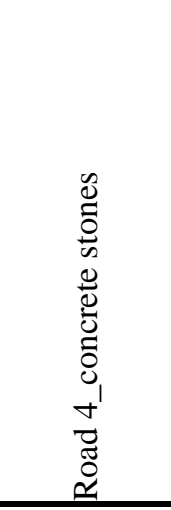 & 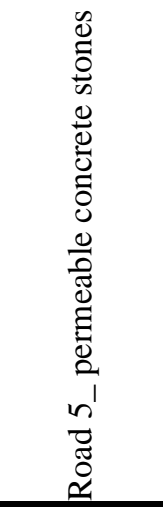 & 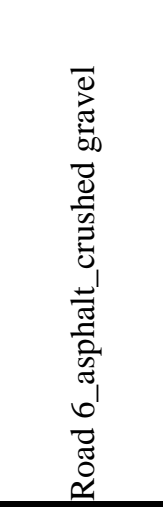 & 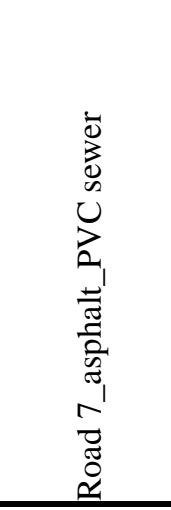 & 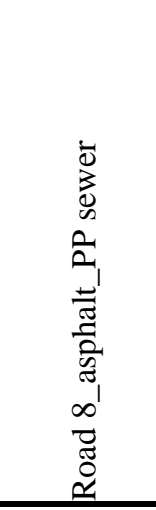 \\
\hline Climate change (kg CO2 eq) & $1.18 \mathrm{E}+03$ & $1.37 \mathrm{E}+03$ & $9.50 \mathrm{E}+02$ & $1.27 \mathrm{E}+03$ & $1.31 \mathrm{E}+03$ & $1.19 \mathrm{E}+03$ & $1.21 \mathrm{E}+03$ & $1.20 \mathrm{E}+03$ \\
\hline Ozone depletion (kg CFC-11 eq) & 1.93E-04 & $9.64 \mathrm{E}-05$ & 7.77E-05 & $9.14 \mathrm{E}-05$ & $9.21 \mathrm{E}-05$ & $1.94 \mathrm{E}-04$ & $1.91 \mathrm{E}-04$ & $1.90 \mathrm{E}-04$ \\
\hline Terrestrial acidification (kg SO2 eq) & $5.27 \mathrm{E}+00$ & $5.43 \mathrm{E}+00$ & 4.47E+00 & $5.17 \mathrm{E}+00$ & $5.26 \mathrm{E}+00$ & $5.30 \mathrm{E}+00$ & $5.25 \mathrm{E}+00$ & $5.15 \mathrm{E}+00$ \\
\hline Eutrophication (kg PO4--- eq) & $3.37 \mathrm{E}+00$ & $2.73 \mathrm{E}+00$ & $2.44 \mathrm{E}+00$ & $2.65 \mathrm{E}+00$ & $2.66 \mathrm{E}+00$ & $3.38 \mathrm{E}+00$ & $3.41 \mathrm{E}+00$ & $3.36 \mathrm{E}+00$ \\
\hline Photochemical oxidant formation (kg C2H4) & $2.40 \mathrm{E}-01$ & $2.25 \mathrm{E}-01$ & $1.90 \mathrm{E}-01$ & 2.18E-01 & $2.20 \mathrm{E}-01$ & $2.41 \mathrm{E}-01$ & $2.45 \mathrm{E}-01$ & $2.41 \mathrm{E}-01$ \\
\hline Abiotic depletion - non fossils (kg Sb eq) & $1.51 \mathrm{E}-02$ & $1.52 \mathrm{E}-02$ & $1.47 \mathrm{E}-02$ & $1.55 \mathrm{E}-02$ & $1.55 \mathrm{E}-02$ & $1.51 \mathrm{E}-02$ & $1.49 \mathrm{E}-02$ & $1.49 \mathrm{E}-02$ \\
\hline Abiotic depletion - fossil (MJ, net cal) & $2.13 \mathrm{E}+04$ & $1.45 \mathrm{E}+04$ & $1.21 \mathrm{E}+04$ & $1.39 \mathrm{E}+04$ & $1.39 \mathrm{E}+04$ & $2.14 \mathrm{E}+04$ & $2.24 \mathrm{E}+04$ & $2.19 \mathrm{E}+04$ \\
\hline Human toxicity (DALY) & 7.59E-04 & 7.73E-04 & 7.34E-04 & 7.67E-04 & 7.67E-04 & $7.60 \mathrm{E}-04$ & $7.68 \mathrm{E}-04$ & 7.61E-04 \\
\hline Particulate matter formation (PM) (DALY) & $2.80 \mathrm{E}-03$ & 3.02E-03 & $2.48 \mathrm{E}-03$ & $2.80 \mathrm{E}-03$ & 2.87E-03 & 2.81E-03 & $2.76 \mathrm{E}-03$ & $2.72 \mathrm{E}-03$ \\
\hline Ionising radiation, human health (DALY) & $1.32 \mathrm{E}-05$ & 1.37E-05 & $1.27 \mathrm{E}-05$ & $1.33 \mathrm{E}-05$ & 1.33E-05 & 1.33E-05 & 1.33E-05 & $1.32 \mathrm{E}-05$ \\
\hline Terrestrial ecotoxicity (kg 1,4-DB eq) & 1.73E-01 & $1.53 \mathrm{E}-01$ & 1.36E-01 & $1.49 \mathrm{E}-01$ & 1.49E-01 & $1.74 \mathrm{E}-01$ & $1.75 \mathrm{E}-01$ & $1.72 \mathrm{E}-01$ \\
\hline Freshwater ecotoxicity (kg 1,4-DB eq) & $1.57 \mathrm{E}+01$ & $1.37 \mathrm{E}+01$ & $1.28 \mathrm{E}+01$ & $1.36 \mathrm{E}+01$ & $1.36 \mathrm{E}+01$ & $1.57 \mathrm{E}+01$ & $1.61 \mathrm{E}+01$ & $1.64 \mathrm{E}+01$ \\
\hline Marine ecotoxicity (kg 1,4-DB eq) & $1.72 \mathrm{E}+01$ & $1.54 \mathrm{E}+01$ & $1.44 \mathrm{E}+01$ & $1.53 \mathrm{E}+01$ & $1.53 \mathrm{E}+01$ & $1.73 \mathrm{E}+01$ & $1.77 \mathrm{E}+01$ & $1.78 \mathrm{E}+01$ \\
\hline Land occupation: forest (species.yr) & $6.29 \mathrm{E}-02$ & $1.86 \mathrm{E}-03$ & 3.99E-02 & $4.71 \mathrm{E}-02$ & $6.26 \mathrm{E}-02$ & $6.29 \mathrm{E}-02$ & $6.29 \mathrm{E}-02$ & $6.29 \mathrm{E}-02$ \\
\hline Urban land occupation (species.yr) & 3.45E-07 & $2.32 \mathrm{E}-07$ & 2.94E-07 & 2.73E-07 & $2.25 \mathrm{E}-07$ & 3.54E-07 & $3.42 \mathrm{E}-07$ & 3.41E-07 \\
\hline Natural land transformation (species.yr) & 1.39E-06 & 1.18E-06 & $1.30 \mathrm{E}-06$ & $1.25 \mathrm{E}-06$ & 1.37E-06 & 2.10E-06 & $1.31 \mathrm{E}-06$ & $1.31 \mathrm{E}-06$ \\
\hline Transformation tropical rain forest (species.yr) & $1.90 \mathrm{E}-08$ & 1.69E-08 & $1.34 \mathrm{E}-08$ & $2.89 \mathrm{E}-08$ & $2.76 \mathrm{E}-08$ & 1.92E-08 & $1.85 \mathrm{E}-08$ & $1.84 \mathrm{E}-08$ \\
\hline Water depletion (m3) & $1.78 \mathrm{E}+01$ & $2.17 \mathrm{E}+01$ & $1.75 \mathrm{E}+01$ & $1.98 \mathrm{E}+01$ & $1.98 \mathrm{E}+01$ & $2.21 \mathrm{E}+01$ & $1.75 \mathrm{E}+01$ & $1.72 \mathrm{E}+01$ \\
\hline
\end{tabular}


Impact category

Climate change (kg CO2 eq)

Ozone depletion (kg CFC-11 eq)

Terrestrial acidification (kg SO2 eq)

Eutrophication (kg PO4--- eq)

Photochemical oxidant formation (kg C2H4)

Abiotic depletion - non fossils (kg Sb eq)

Abiotic depletion - fossil (MJ, net cal)

Human toxicity (DALY)

Particulate matter formation (PM) (DALY)

Ionising radiation, human health (DALY)

Terrestrial ecotoxicity (kg 1,4-DB eq)

Freshwater ecotoxicity (kg 1,4-DB eq)

Marine ecotoxicity (kg 1,4-DB eq)

Land occupation: forest (species.yr)

Urban land occupation (species.yr)

Natural land transformation (species.yr)

Transformation tropical rain forest (species.yr)

Water depletion (m3)

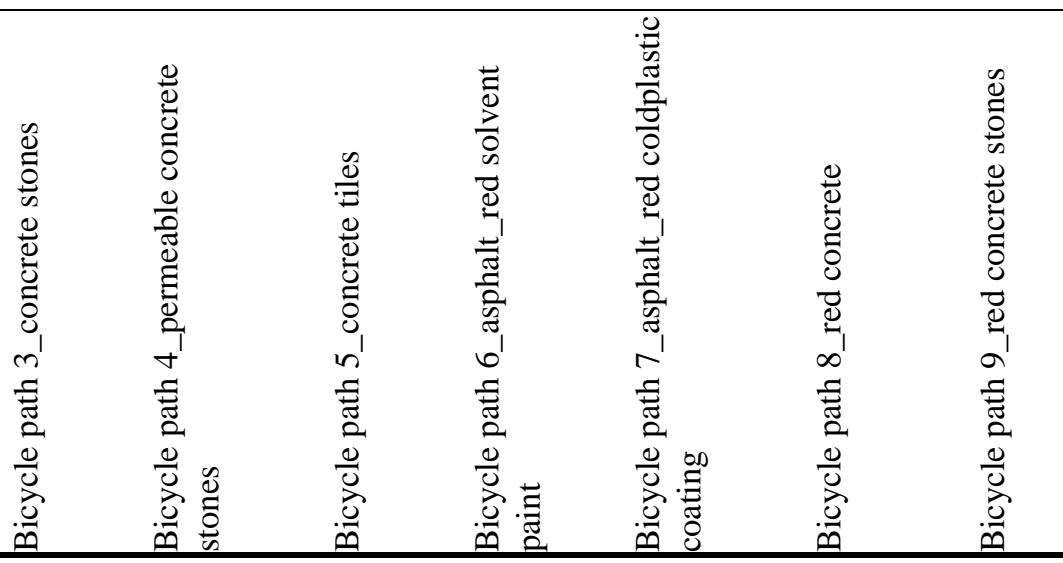

$\begin{array}{lllllllll}1.45 \mathrm{E}+02 & 1.73 \mathrm{E}+02 & 1.75 \mathrm{E}+02 & 1.90 \mathrm{E}+02 & 1.15 \mathrm{E}+02 & 2.08 \mathrm{E}+02 & 6.10 \mathrm{E}+02 & 1.73 \mathrm{E}+02 & 1.75 \mathrm{E}+02\end{array}$

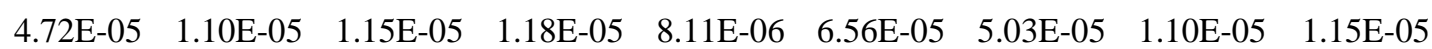

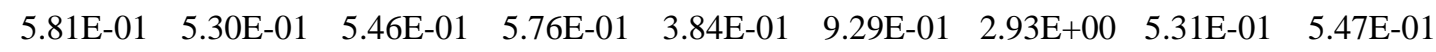
$\begin{array}{lllllllll}4.16 \mathrm{E}-01 & 1.60 \mathrm{E}-01 & 1.62 \mathrm{E}-01 & 1.66 \mathrm{E}-01 & 1.15 \mathrm{E}-01 & 5.37 \mathrm{E}-01 & 6.99 \mathrm{E}-01 & 1.60 \mathrm{E}-01 & 1.62 \mathrm{E}-01\end{array}$

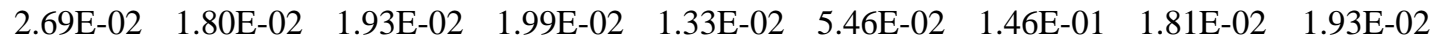
$\begin{array}{lllllllll}3.18 \mathrm{E}-04 & 2.88 \mathrm{E}-04 & 4.82 \mathrm{E}-04 & 4.69 \mathrm{E}-04 & 3.18 \mathrm{E}-04 & 1.13 \mathrm{E}-03 & 1.84 \mathrm{E}-03 & 2.88 \mathrm{E}-04 & 4.82 \mathrm{E}-04\end{array}$ $\begin{array}{lllllllll}4.01 \mathrm{E}+03 & 1.35 \mathrm{E}+03 & 1.39 \mathrm{E}+03 & 1.42 \mathrm{E}+03 & 9.83 \mathrm{E}+02 & 6.55 \mathrm{E}+03 & 1.18 \mathrm{E}+04 & 1.35 \mathrm{E}+03 & 1.39 \mathrm{E}+03\end{array}$ $\begin{array}{lllllllll}1.69 \mathrm{E}-05 & 1.83 \mathrm{E}-05 & 1.98 \mathrm{E}-05 & 2.00 \mathrm{E}-05 & 1.35 \mathrm{E}-05 & 3.81 \mathrm{E}-05 & 3.44 \mathrm{E}-05 & 1.83 \mathrm{E}-05 & 1.98 \mathrm{E}-05\end{array}$ 3.39E-04 3.48E-04 3.40E-04 3.61E-04 2.50E-04 $\quad 4.80 \mathrm{E}-04 \quad 1.02 \mathrm{E}-03 \quad 3.54 \mathrm{E}-04 \quad 3.43 \mathrm{E}-04$ $\begin{array}{lllllllll}3.58 \mathrm{E}-07 & 4.18 \mathrm{E}-07 & 3.80 \mathrm{E}-07 & 3.87 \mathrm{E}-07 & 2.64 \mathrm{E}-07 & 6.19 \mathrm{E}-07 & 4.90 \mathrm{E}-07 & 4.18 \mathrm{E}-07 & 3.80 \mathrm{E}-07\end{array}$

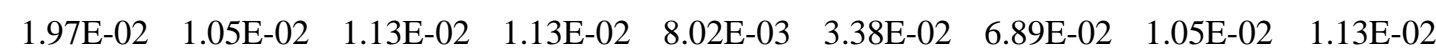
$\begin{array}{lllllllll}1.25 \mathrm{E}+00 & 4.75 \mathrm{E}-01 & 5.32 \mathrm{E}-01 & 5.26 \mathrm{E}-01 & 3.71 \mathrm{E}-01 & 1.84 \mathrm{E}+00 & 4.41 \mathrm{E}+00 & 4.75 \mathrm{E}-01 & 5.32 \mathrm{E}-01\end{array}$

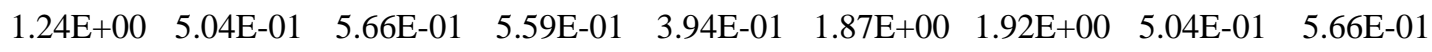

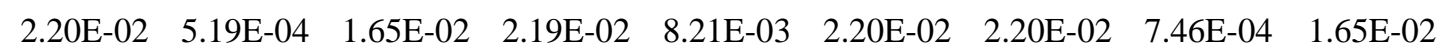
$\begin{array}{lllllllll}7.68 \mathrm{E}-08 & 3.05 \mathrm{E}-08 & 5.15 \mathrm{E}-08 & 3.48 \mathrm{E}-08 & 3.84 \mathrm{E}-08 & 9.04 \mathrm{E}-08 & 8.95 \mathrm{E}-08 & 3.05 \mathrm{E}-08 & 5.15 \mathrm{E}-08\end{array}$ $\begin{array}{lllllllll}1.26 \mathrm{E}-07 & 4.38 \mathrm{E}-08 & 7.73 \mathrm{E}-08 & 1.22 \mathrm{E}-07 & 5.86 \mathrm{E}-08 & 2.13 \mathrm{E}-07 & 1.28 \mathrm{E}-07 & 4.38 \mathrm{E}-08 & 7.73 \mathrm{E}-08\end{array}$ 3.68E-09 2.50E-09 7.15E-09 6.68E-09 4.42E-09 5.13E-09 $\quad 4.08 \mathrm{E}-09 \quad 2.50 \mathrm{E}-09 \quad 7.15 \mathrm{E}-09$

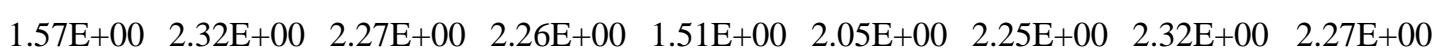

Table S. 7 Life cycle environmental impact of the bicycle path sections analysed, subdivided per impact category (characterized results) 


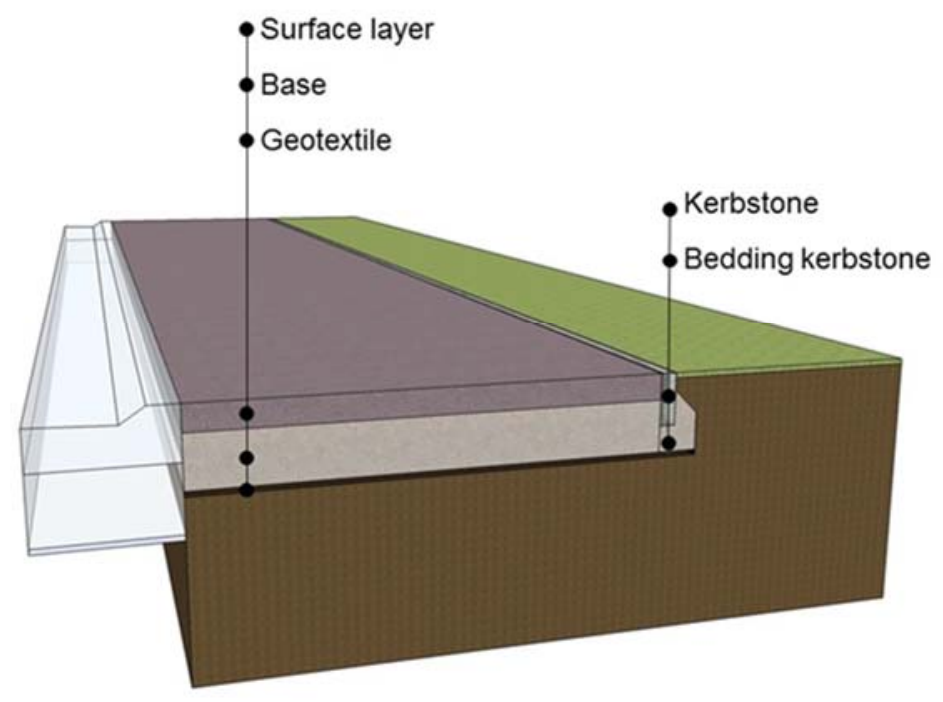

16 Fig. S. 1 3D section of the bicycle path sections analysed along the existing kerbstone of the road (excluded for this calculation) 
floor area

compactness C

protected (heated) volume $\mathrm{V}$

dwelling skin surface $\mathrm{A}_{\mathrm{T}}$
$123 \mathrm{~m}^{2}$

$1,18 \mathrm{~m}$

$382 \mathrm{~m}^{3}$

$324 \mathrm{~m}^{2}$
19

20

21

22

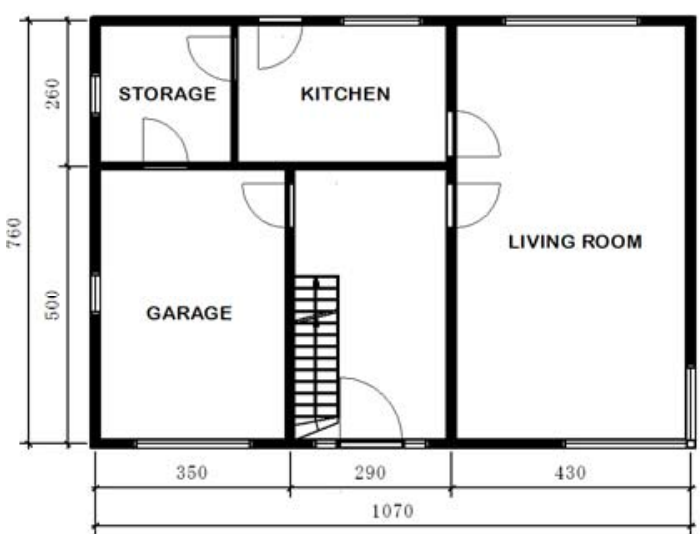

GROUND FLOOR
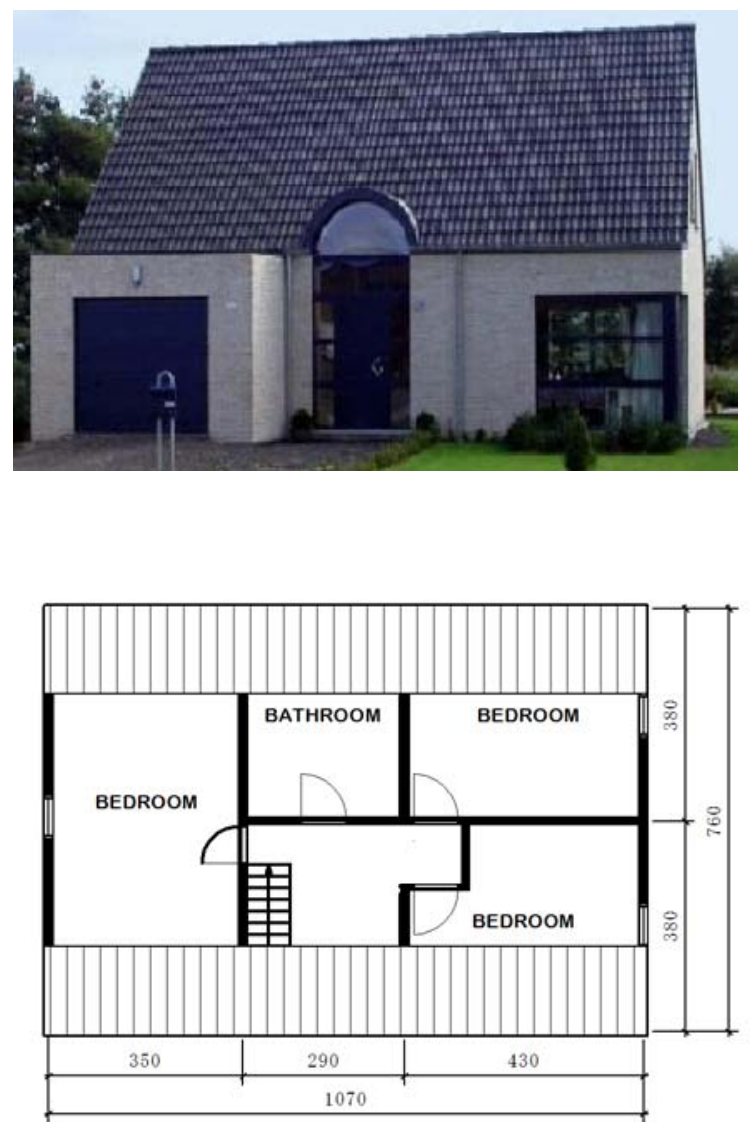

LEVEL 1

Element table

\begin{tabular}{llrl}
\hline BB/SfB code & Element & amount & unit \\
\hline$(13 .+)$ & floor on grade & 81 & $\mathrm{~m}^{2}$ \\
$(21 .+)$ & external wall & 103 & $\mathrm{~m}^{2}$ \\
$\left(22.1^{+}\right)$ & loadbearing internal wall & 53 & $\mathrm{~m}^{2}$ \\
$\left(22.3^{+}\right)$ & non-bearing internal wall & 86 & $\mathrm{~m}^{2}$ \\
$(23 .+)$ & floor & 78 & $\mathrm{~m}^{2}$ \\
$(24 .+)$ & stairs & 1 & $\mathrm{p}$ \\
$(27.2+)$ & pitched roof & 81 & $\mathrm{~m}^{2}$ \\
$(31 .+)$ & windows and external doors & 30 & $\mathrm{~m}^{2}$ \\
$(32 .+)$ & internal doors & 9 & $\mathrm{p}$ \\
\hline
\end{tabular}

25

Fig. S. 2 Representation of the selected detached house (Allacker 2010) 
floor area

compactness C

protected (heated) volume $\mathrm{V}$

dwelling skin surface $\mathrm{A}_{\mathrm{T}}$
$144 \mathrm{~m}^{2}$

$1,60 \mathrm{~m}$

$525 \mathrm{~m}^{3}$

$329 \mathrm{~m}^{2}$

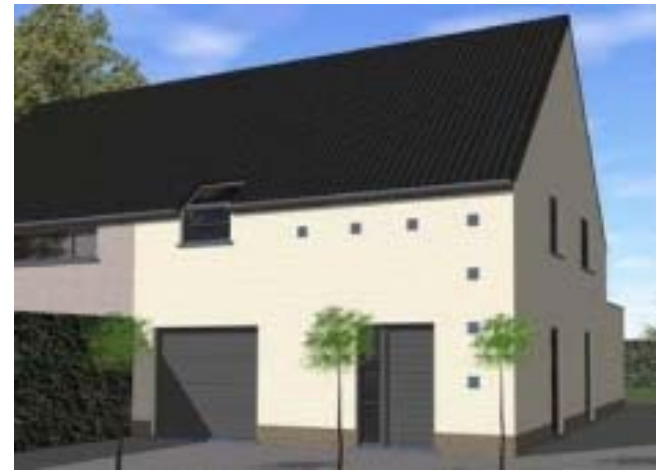

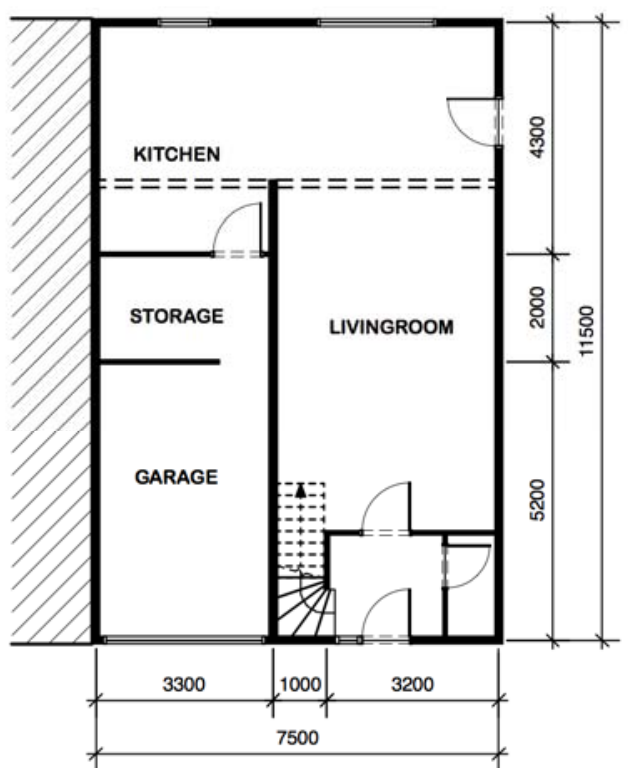

GROUND FLOOR

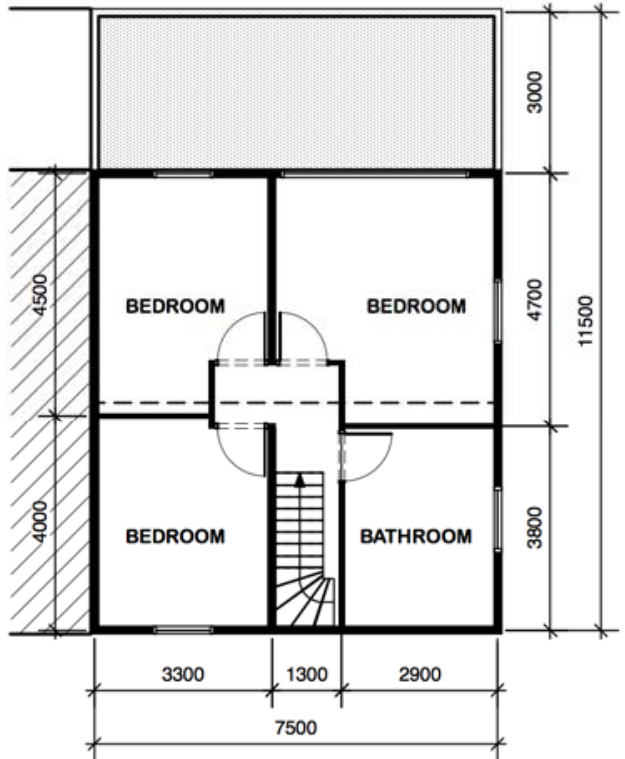

LEVEL 1

Element table

\begin{tabular}{llrl}
\hline BB/SfB code & Element & amount & unit \\
\hline$(13 .+)$ & floor on grade & 86 & $\mathrm{~m}^{2}$ \\
$(21 .+)$ & external wall & 104 & $\mathrm{~m}^{2}$ \\
$\left.(22 .)^{+}\right)$ & loadbearing internal wall & 42 & $\mathrm{~m}^{2}$ \\
$\left(22.3^{+}\right)$ & non-loadbearing internal wall & 48 & $\mathrm{~m}^{2}$ \\
$(22.8+)$ & separating wall & 65 & $\mathrm{~m}^{2}$ \\
$(23 .+)$ & floor & 60 & $\mathrm{~m}^{2}$ \\
$(24 .+)$ & stairs & 1 & $\mathrm{p}$ \\
$(27.1+)$ & flat roof & 23 & $\mathrm{~m}^{2}$ \\
$(27.2+)$ & pitched roof & 64 & $\mathrm{~m}^{2}$ \\
$(31 .+)$ & windows and external doors & 25 & $\mathrm{~m}^{2}$ \\
$(32 .+)$ & internal doors & 7 & $\mathrm{p}$ \\
\hline
\end{tabular}

Fig. S. 3 Representation of the selected semi-detached house (Allacker 2010) 
floor area

compactness $\mathrm{C}$

protected (heated) volume $\mathrm{V}$

dwelling skin surface $\mathrm{A}_{\mathrm{T}}$
32

33

34

35

36

37

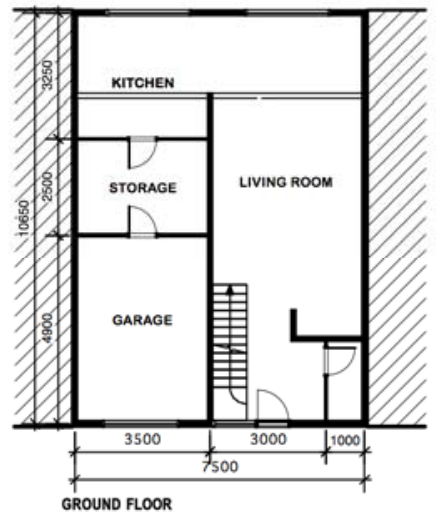

$200 \mathrm{~m}^{2}$

1,96 m

$549 \mathrm{~m}^{3}$

$280 \mathrm{~m}^{2}$
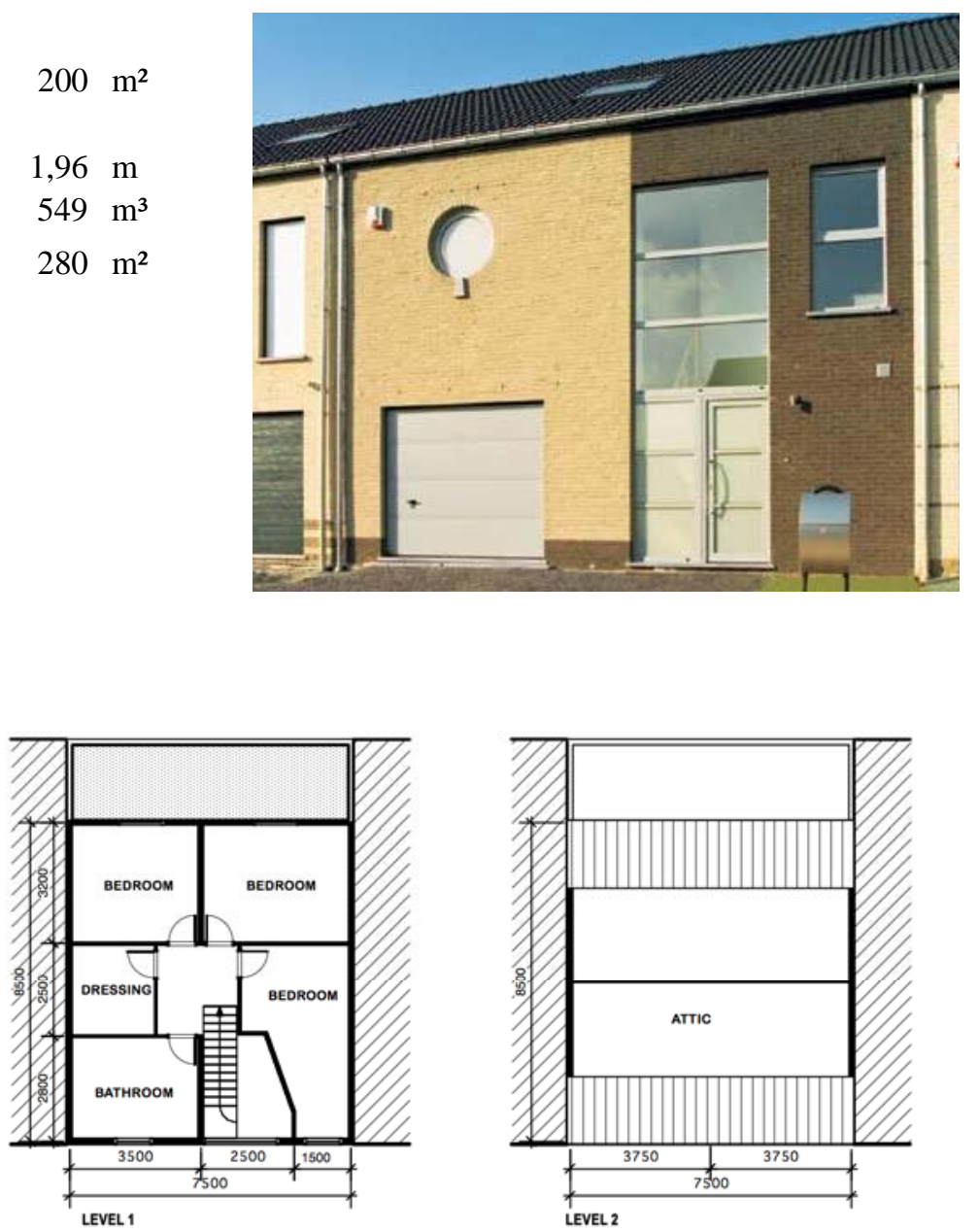

38

39

Element table

\begin{tabular}{llrl}
\hline BB/SfB & Element & amount & unit \\
\hline$(13 .+)$ & floor on grade & 80 & $\mathrm{~m}^{2}$ \\
$(21 .+)$ & external wall & 87 & $\mathrm{~m}^{2}$ \\
$\left(22.1^{+}\right)$ & loadbearing internal wall & 38 & $\mathrm{~m}^{2}$ \\
$\left(22.3^{+}\right)$ & non-loadbearing internal wall & 69 & $\mathrm{~m}^{2}$ \\
$(22.8+)$ & separating wall & 126 & $\mathrm{~m}^{2}$ \\
$(23 .+)$ & floor & 61 & $\mathrm{~m}^{2}$ \\
$(24 .+)$ & stairs & 2 & $\mathrm{p}$ \\
$(23 \mathrm{a}+)$ & attic floor & 61 & $\mathrm{~m}^{2}$ \\
$(27.1+)$ & flat roof & 16 & $\mathrm{~m}^{2}$ \\
$(27.2+)$ & pitched roof & 64 & $\mathrm{~m}^{2}$ \\
$(31 .+)$ & windows and external doors & 24 & $\mathrm{~m}^{2}$ \\
$(32 .+)$ & internal doors & 8 & $\mathrm{p}$ \\
\hline
\end{tabular}

40

Fig. S. 4 Representation of the selected terraced house (Allacker 2010) 
43

floor area

compactness C

protected (heated) volume $\mathrm{V}$

dwelling skin surface $\mathrm{A}_{\mathrm{T}}$
$143 \mathrm{~m}^{2}$

$1,58 \mathrm{~m}$

$298 \mathrm{~m}^{3}$

$189 \mathrm{~m}^{2}$
44

45

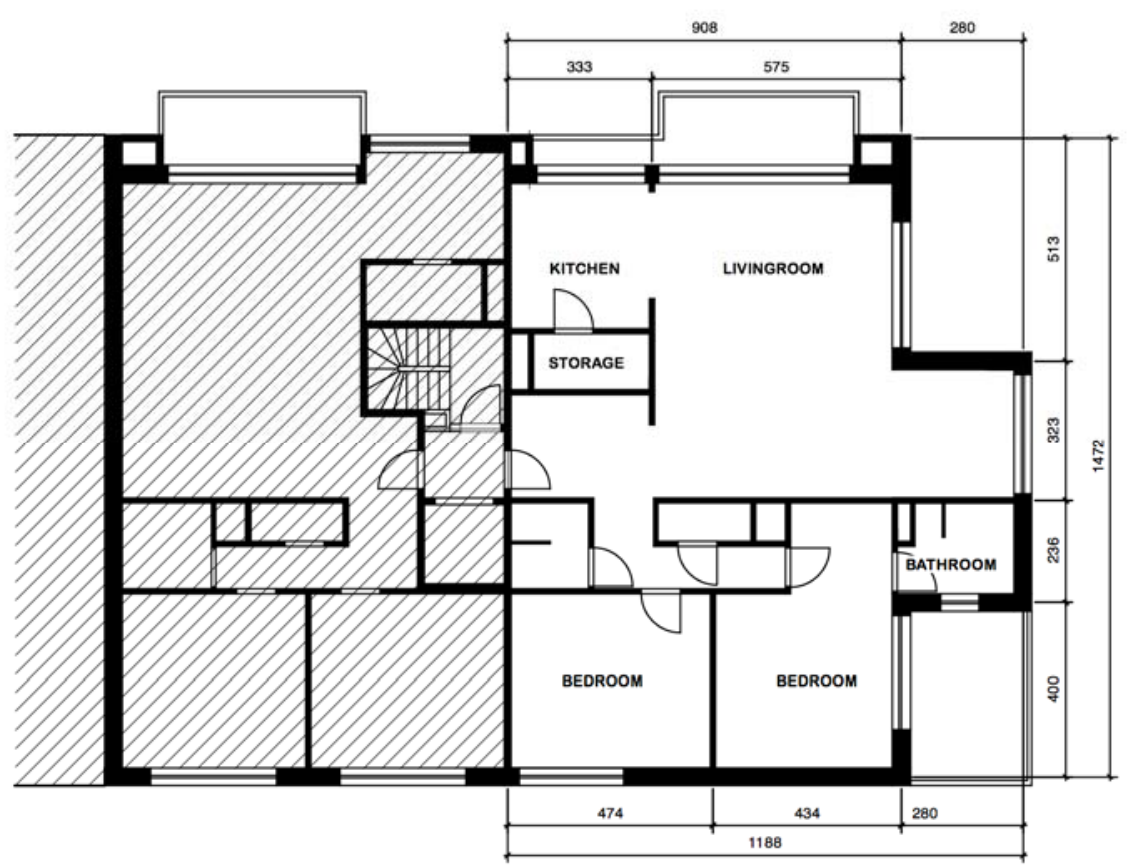

46

47

48

Fig. S. 5 Representation of the selected apartment (Allacker 2010)

Element table

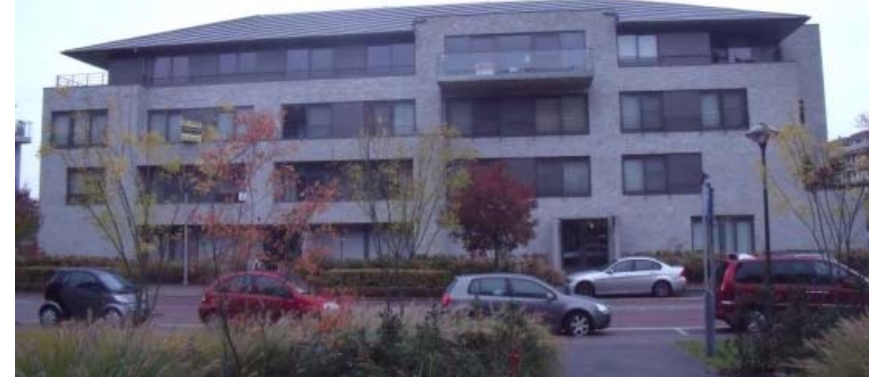

\begin{tabular}{llrl}
\hline BB/SfB code & Element & amount & unit \\
\hline$(13 .+)$ & floor on grade & 36 & $\mathrm{~m}^{2}$ \\
$(21 .+)$ & external wall & 74 & $\mathrm{~m}^{2}$ \\
$\left(22.1^{+}\right)$ & loadbearing internal wall & 44 & $\mathrm{~m}^{2}$ \\
$(22.3+)$ & non-loadbearing internal wall & 78 & $\mathrm{~m}^{2}$ \\
$(22.8+)$ & shared wall & 12 & $\mathrm{~m}^{2}$ \\
$(23 .+)$ & floor & 151 & $\mathrm{~m}^{2}$ \\
$(24 .+)$ & stairs & 0.5 & $\mathrm{p}$ \\
$(27.1+)$ & flat roof & 40 & $\mathrm{~m}^{2}$ \\
$(31)$. & windows and external doors & 39 & $\mathrm{~m}^{2}$ \\
$(32)$. & internal doors & 7 & $\mathrm{p}$ \\
\hline
\end{tabular}




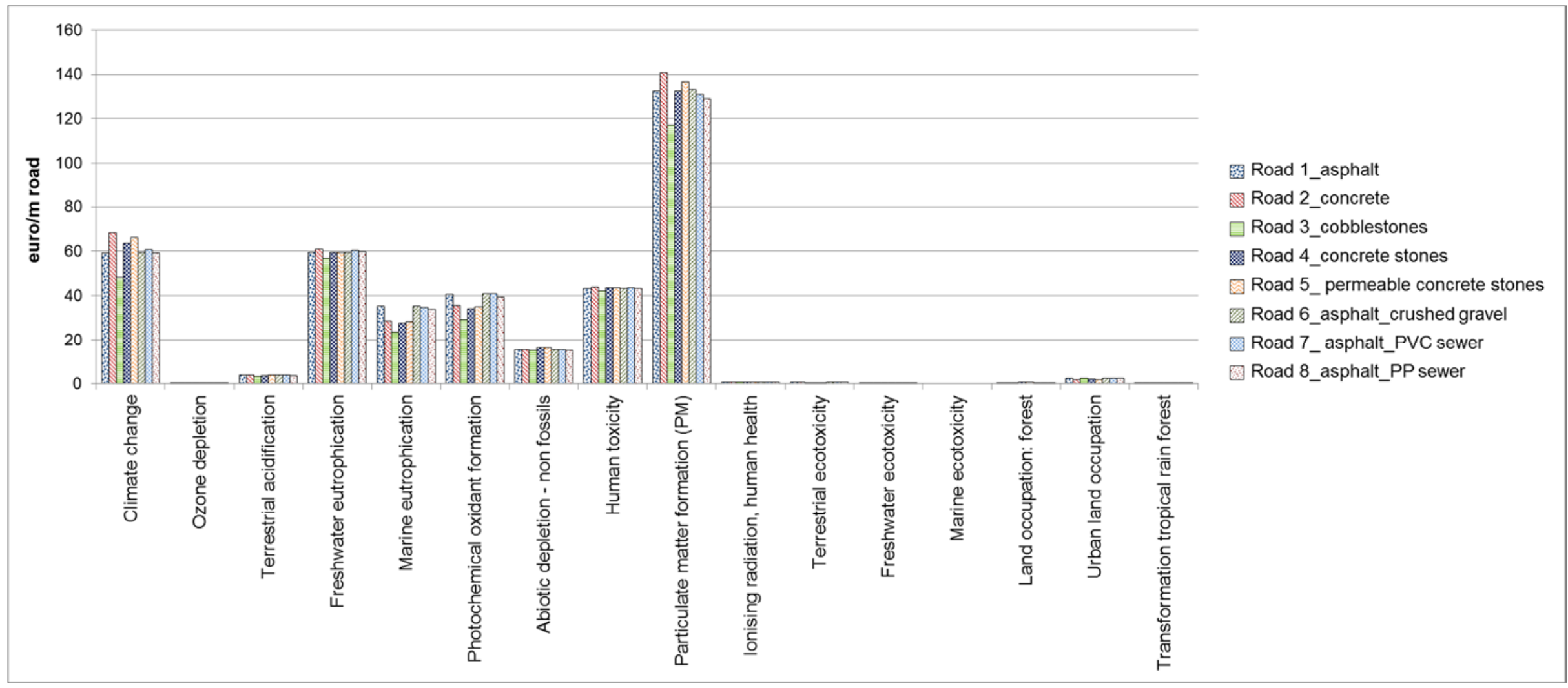

Fig. S. 6 Life cycle environmental cost (median scenario) of the road sections analysed, subdivided per impact category 


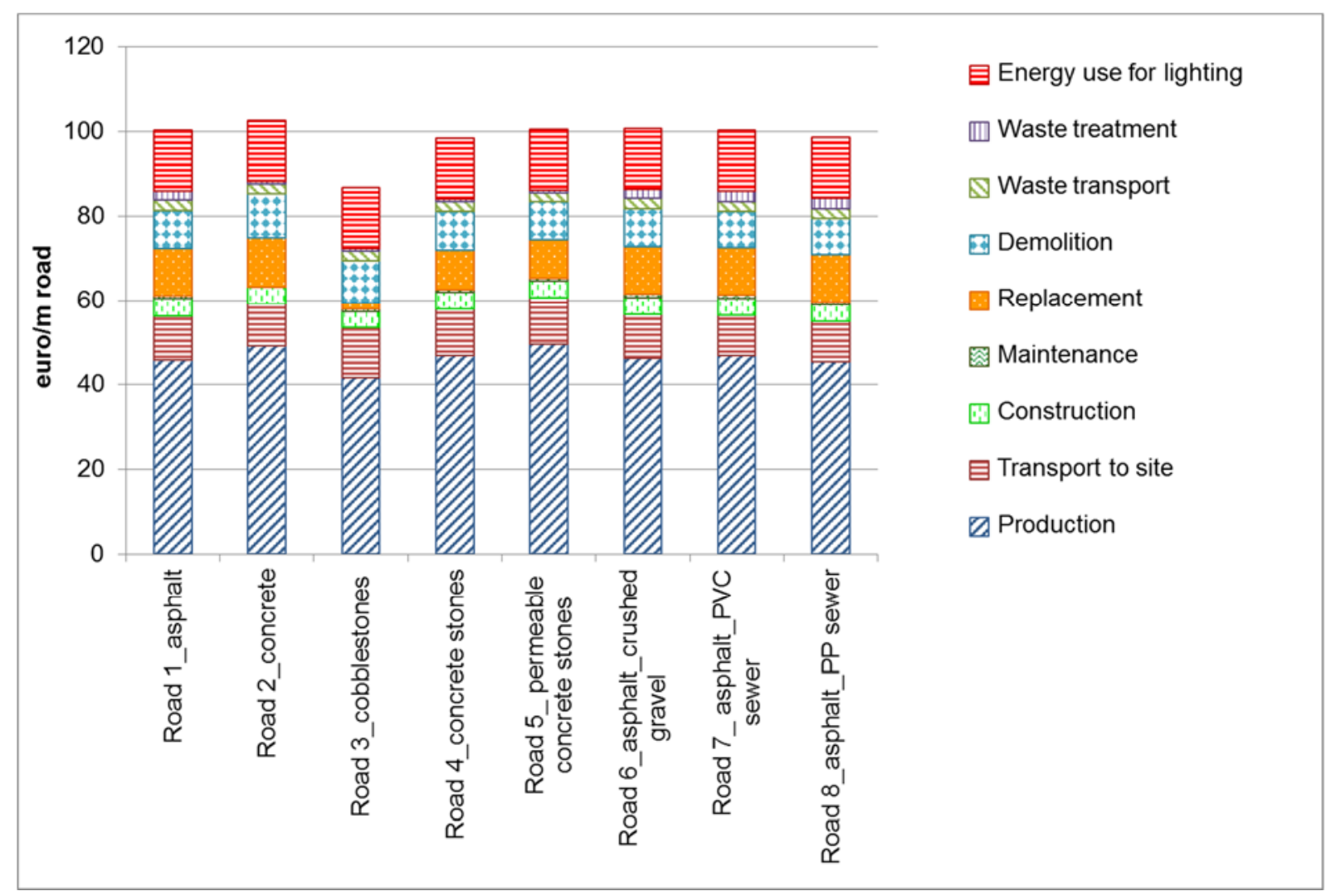

Fig. S. 7 Life cycle environmental cost (minimum scenario) of the road sections analysed, subdivided per life cycle phase

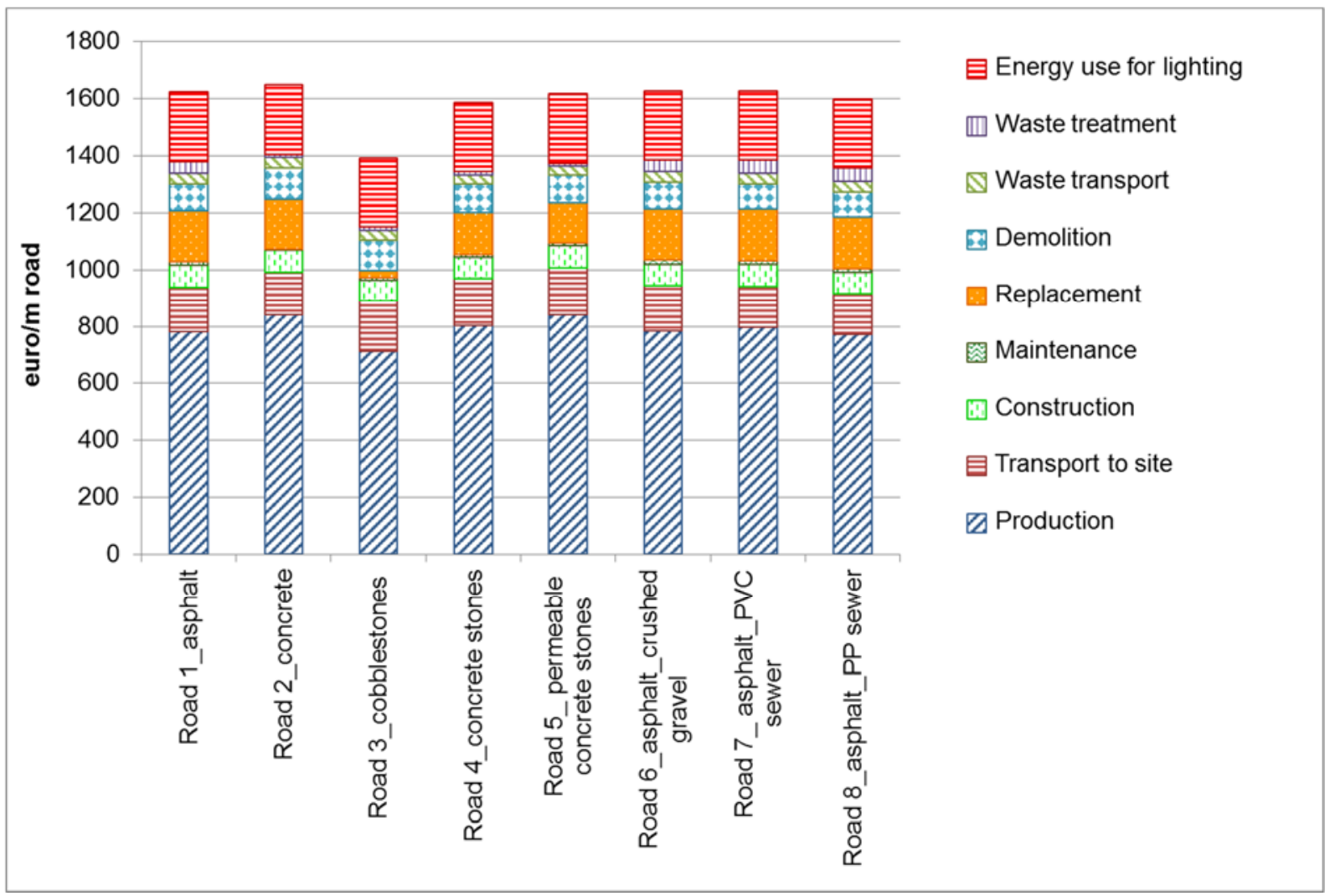

Fig. S. 8 Life cycle environmental cost (maximum scenario) of the road sections analysed, subdivided per life cycle phase 


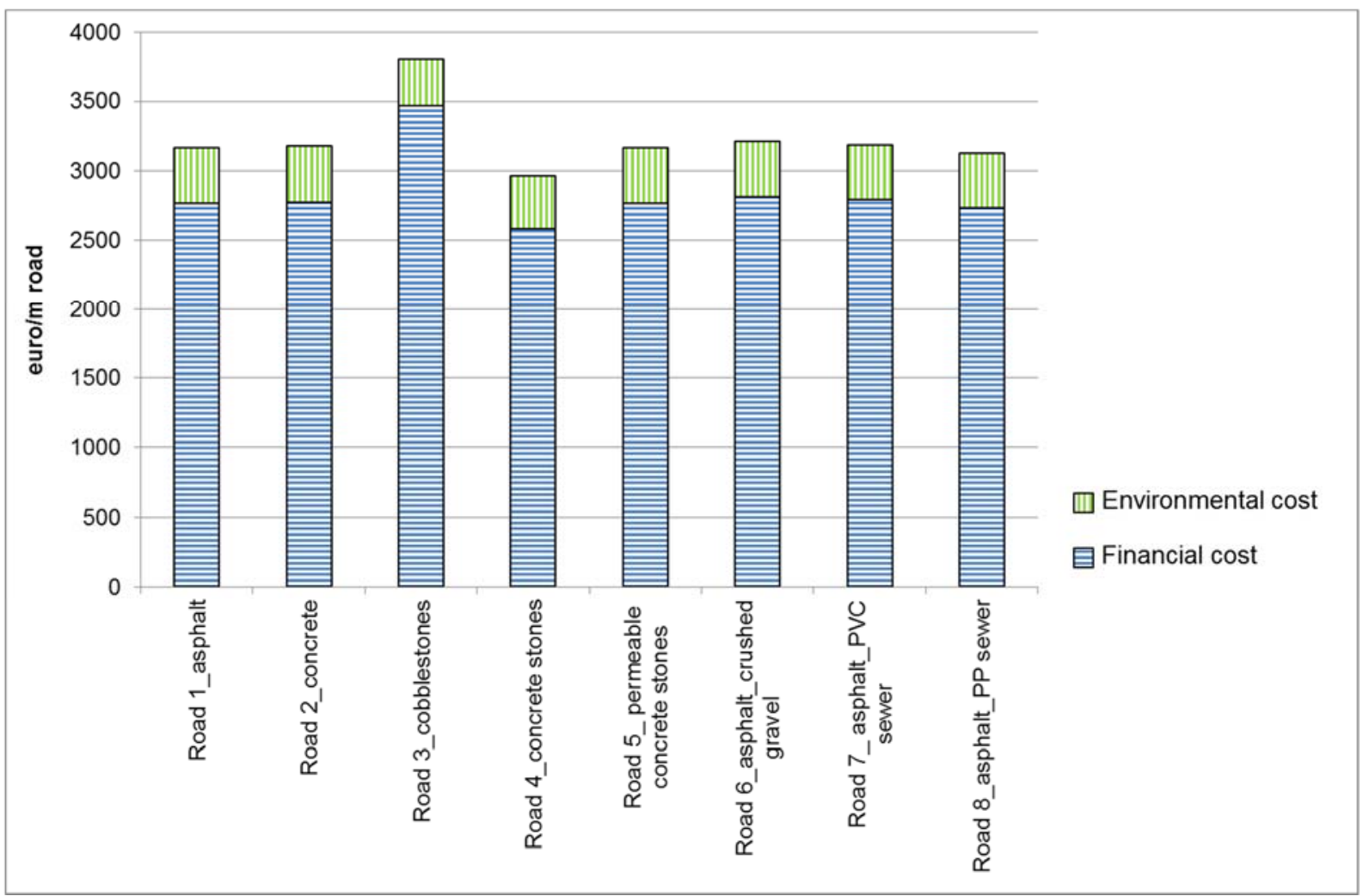

61 Fig. S. 9 Life cycle total cost of the road sections analysed, subdivided in financial and environmental cost. The 62 environmental cost is calculated based on the median scenario.

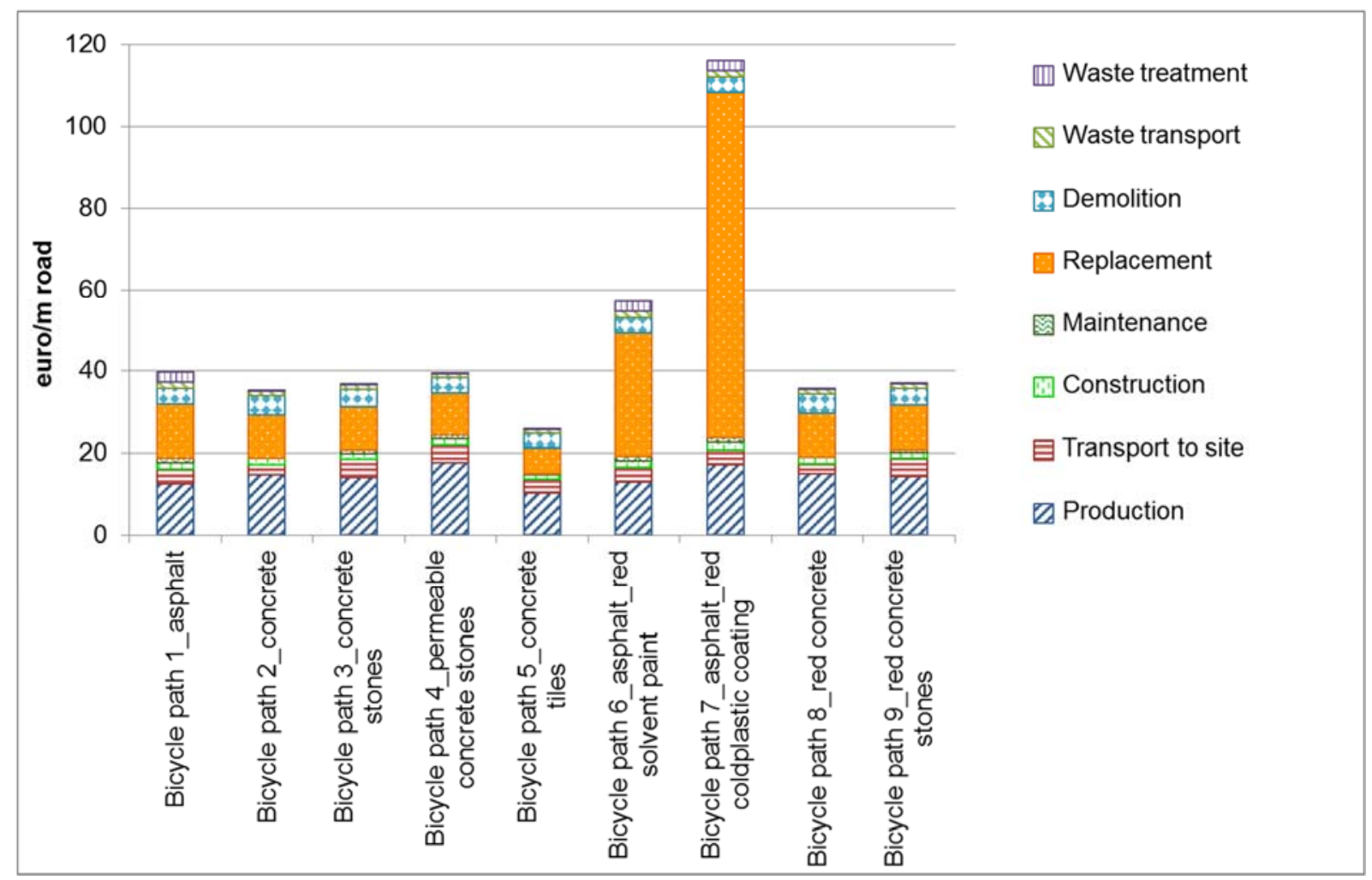

Fig. S. 10 Life cycle environmental cost (median scenario) of the bicycle paths analysed, subdivided per life cycle 65 phase 


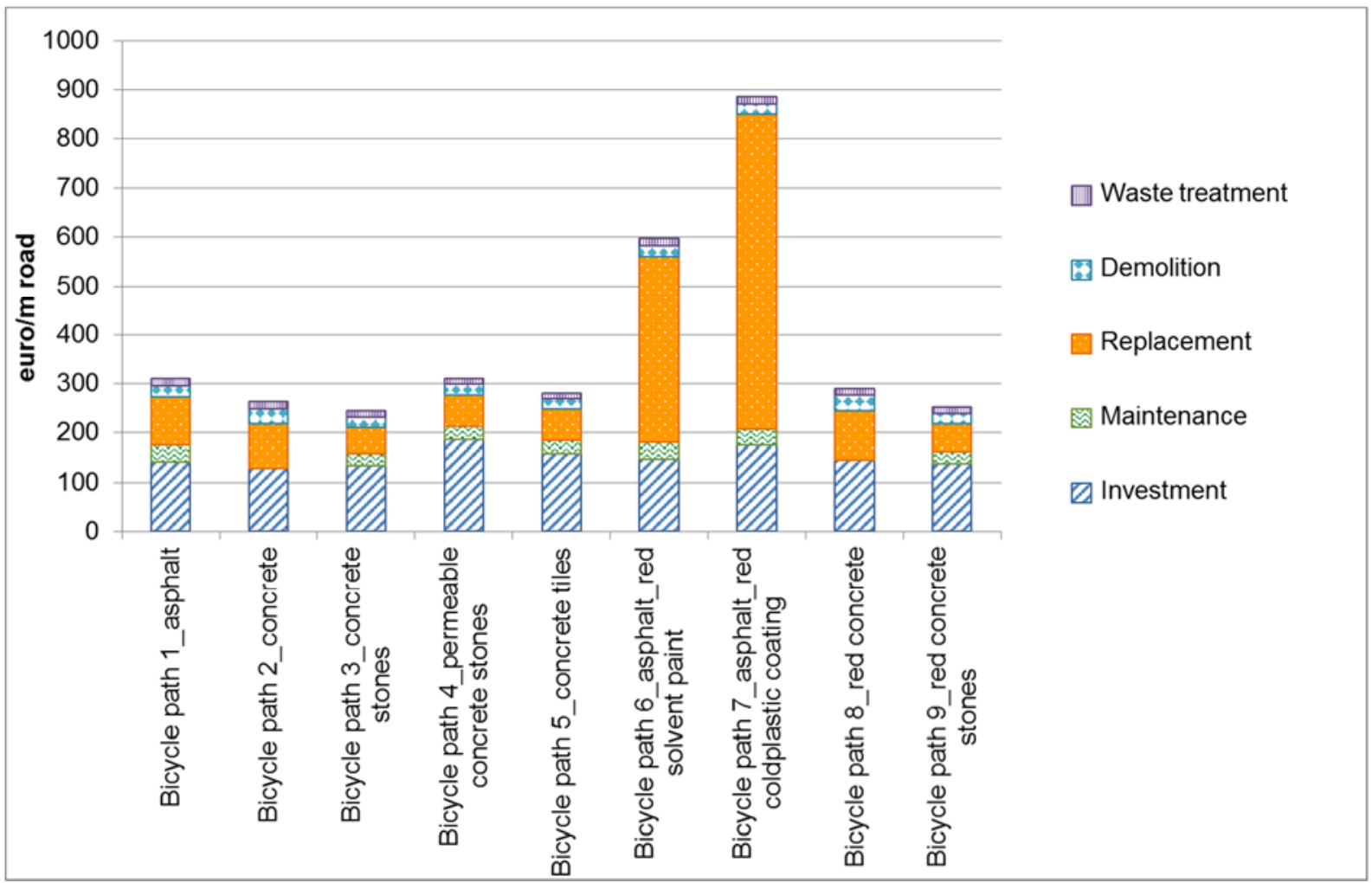

Fig. S. 11 Life cycle financial cost of the bicycle paths analysed, subdivided per life cycle phase 